\title{
Macroalgae as a Biomass Feedstock: A Preliminary Analysis
}

G. Roesijadi

S.B. Jones

L. J. Snowden-Swan

Y. Zhu

September 2010

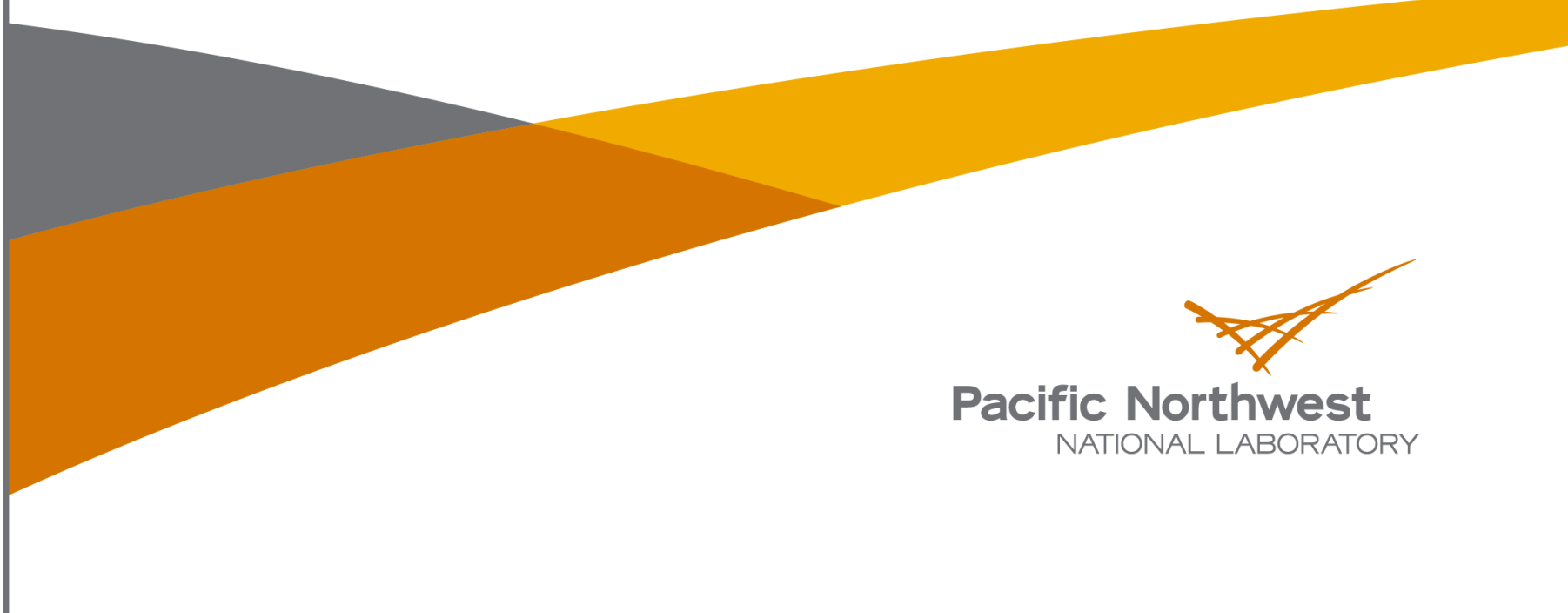




\title{
DISCLAIMER
}

This report was prepared as an account of work sponsored by an agency of the United States Government. Neither the United States Government nor any agency thereof, nor Battelle Memorial Institute, nor any of their employees, makes any warranty, express or implied, or assumes any legal liability or responsibility for the accuracy, completeness, or usefulness of any information, apparatus, product, or process disclosed, or represents that its use would not infringe privately owned rights. Reference herein to any specific commercial product, process, or service by trade name, trademark, manufacturer, or otherwise does not necessarily constitute or imply its endorsement, recommendation, or favoring by the United States Government or any agency thereof, or Battelle Memorial Institute. The views and opinions of authors expressed herein do not necessarily state or reflect those of the United States Government or any agency thereof.

\author{
PACIFIC NORTHWEST NATIONAL LABORATORY \\ operated by \\ BATTELLE \\ for the \\ UNITED STATES DEPARTMENT OF ENERGY \\ under Contract DE-AC05-76RL01830
}

Printed in the United States of America

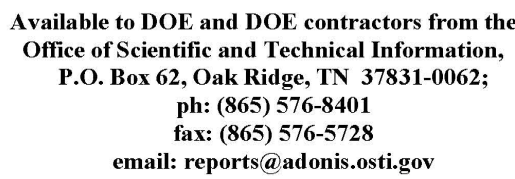

Available to the public from the National Technical Information Service, U.S. Department of Commerce, 5285 Port Royal Rd., Springfield, VA 22161 ph: (800) 553-6847 fax: $(703) 605-6900$

email: orders@ntis.fedworld.gov

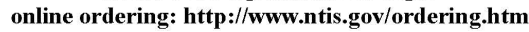

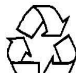

This document was printed on recycled paper

(9/2003) 


\title{
Macroalgae as a Biomass Feedstock: A Preliminary Analysis
}

\author{
G. Roesijadi \\ S.B. Jones \\ L.J. Snowden-Swan \\ Y. Zhu
}

September 2010

Prepared for

the U.S. Department of Energy

under Contract DE-AC05-76RL01830

Pacific Northwest National Laboratory

Richland, Washington 99352 



\section{Preface}

Meeting the Energy Independence and Security Act (EISA) renewable fuels goals requires development of a large sustainable domestic supply of diverse biomass feedstocks. Macroalgae, also known as seaweed, could be a potential contributor toward this goal. This resource would be grown in marine waters under U.S. jurisdiction and would not compete with existing land-based energy crops.

Very little analysis has been done on this resource to date. This report provides information needed for an initial assessment of the development of macroalgae as a feedstock for the biofuels industry.

The findings suggest that the marine biomass resource potential for the United States is very high based on the surface area of the marine waters of the U.S. and rates of commercial macroalgae production in other parts of the world. However, macroalgae cultivation for fuels production is likely a long term effort. Analysis of the available data showed that considerable scale up in cultivation over current world-wide production and improvements in processing throughout the supply chain are needed.

Despite the high resource potential, the United States does not currently have a macroalgae production industry and would have to develop this capability. In order to meet current renewable fuels goals, the scale of the effort would have to be high in comparison with activity in other parts of the world. For example, replacing $1 \%$ of the domestic gasoline supply with macroalgae would require annual production rates about ten and one-half times current worldwide production. This could be accomplished through cultivation on $10,895 \mathrm{~km}^{2}$ of ocean surface, based on current rates of production reported for the international macroalgae cultivation industry. Advances in cultivation technology already being tested could potentially increase production from three to ten fold with a corresponding decrease in the area needed for cultivation to meet specified production goals. While it is no surprise that the cost estimates to produce fuel from macroalgae are currently high, it should be noted that this is based on a limited amount of available data and that production costs for macroalgae can benefit from increased efficiency and scale.

A thorough analysis is warranted due to the size of this biomass resource and the need to consider all potential sources of feedstock to meet current biomass production goals. Understanding how to harness this untapped biomass resource will require additional research and development. A detailed assessment of environmental resources, cultivation and harvesting technology, conversion to fuels, connectivity with existing energy supply chains, and the associated economic and life cycle analyses will facilitate evaluation of this potentially important biomass resource. 


\section{Table of Contents}

Preface

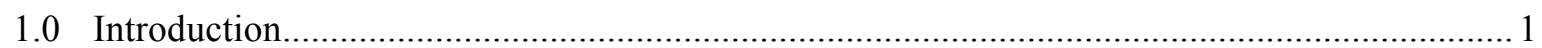

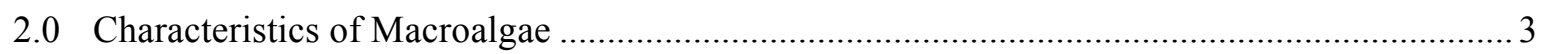

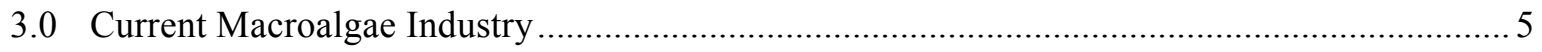

4.0 Preliminary Resource Assessment for Macroalgal Production in the United States................. 8

5.0 Past and Current Activities in Macroalgal Biofuels ................................................................ 11

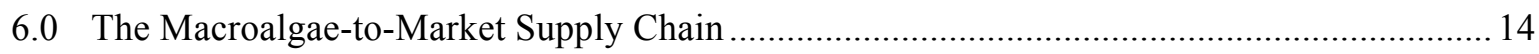

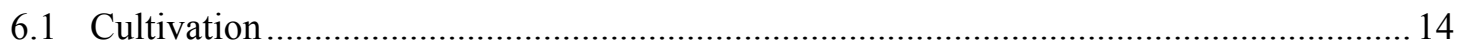

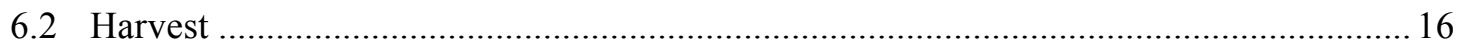

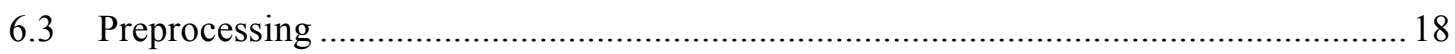

6.4 Types of Biofuels and Conversion Technology for Macroalgae ..................................... 19

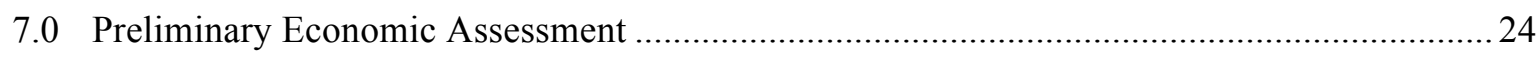

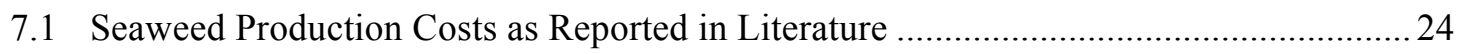

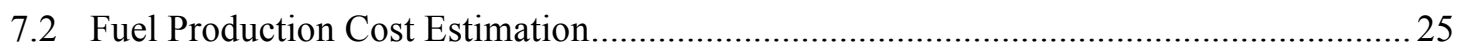

7.2.1 Gasoline from Seaweed via Digestion and MTG Production Description.....................25

7.2.2 Ethanol from Seaweed Fermentation Production Description ....................................26

7.2.3 Gasoline and Diesel via HTL and Bio-Oil Upgrading Production Description ............27

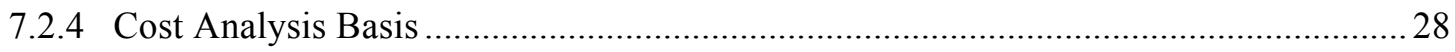

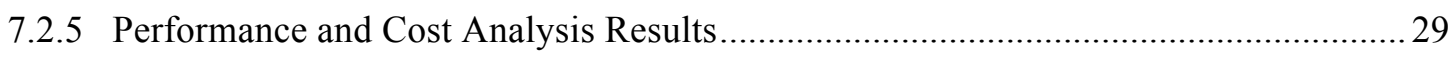

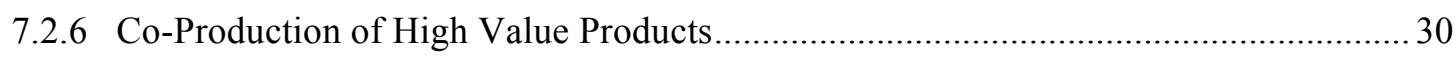

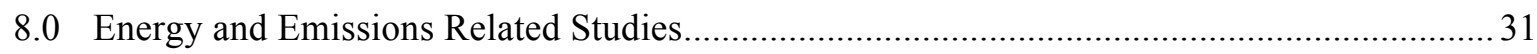

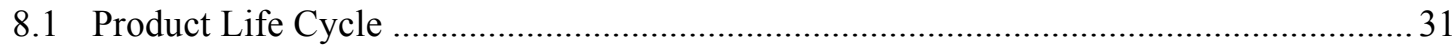

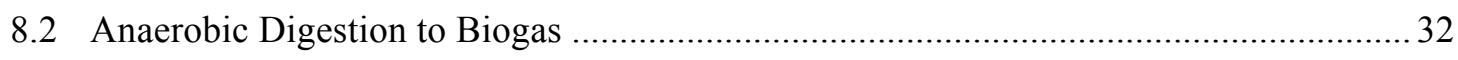

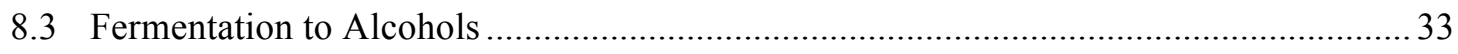

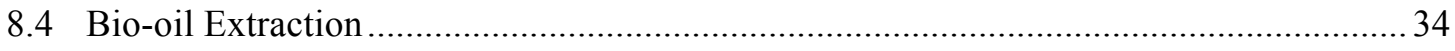

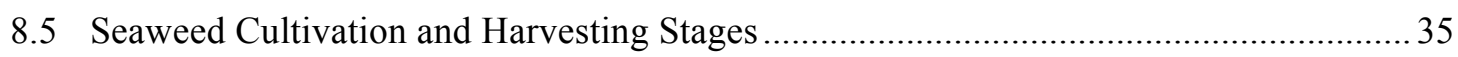

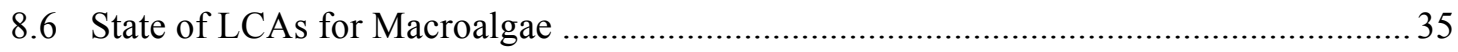

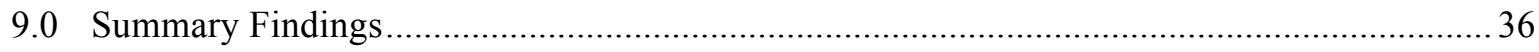

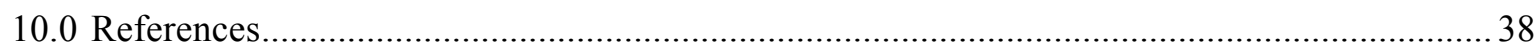




\section{List of Figures}

Figure 1. The gross morphology of a young Saccharina latissima, a kelp .................................... 3

Figure 2. Generic representation of alternating life cycle of seaweeds (Collado-Vides 2001) ......... 4

Figure 3. U.S. Exclusive Economic Zone (http://aquaculture.noaa.gov/pdf.20 eezmap.pdf)........... 8

Figure 4. Seaweed processing plant for production of methane and electricity (Matsui et al. 2006).

Figure 5. Production stages for the farming of Japanese kelp Laminaria japonica in China.......... 15

Figure 6. Hercules Powder Company's harvester, Bacchus (Whitney 1987)............................... 17

Figure 7. Harvest of Laminaria hyperborea grown on an offshore ring structure in the North Sea

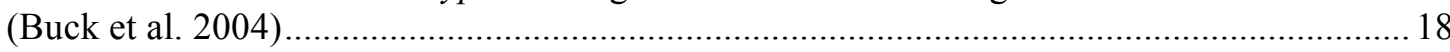

Figure 8. Block flow for seaweed production process.............................................................. 24

Figure 9. Block flow for seaweed to gasoline via digestion and MTG ........................................25

Figure 10. Block flow for seaweed to bioethanol via fermentation...........................................27

Figure 11. Block flow for seaweed to gasoline and diesel via HTL and upgrading.....................27

Figure 12. Affect of methane yield on minimum feedstock price for the MTG process................ 30

Figure 13. Primary steps in the macroalgal fuel life cycle............................................................ 31 


\section{List of Tables}

Table 1. Global value of seaweed products per annum (McHugh 2003)... 5

Table 2. World production (metric ton) and value (USD) of harvested and cultured macroalgae

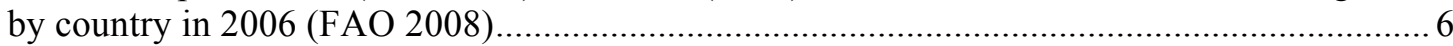

Table 3. World-wide farmed seaweed production in 2004 by taxa (Roesijadi et al. 2008)............. 7

Table 4. Area and percent of EEZ needed to meet MYPP (EERE 2010) target using marine biomass (estimated using an average production estimate of 2960 dry metric ton $/ \mathrm{km}^{2} / \mathrm{yr}$ ) ${ }^{1} \ldots . .9$

Table 5. Macroalgal production and gasoline equivalents to meet a 1\% US gasoline displacement target.

Table 6. Companies currently engaged in macroalgae to fuels production ${ }^{1}$.................................. 13

Table 7. Supply chain considerations (Bruton et al. 2009). ......................................................... 14

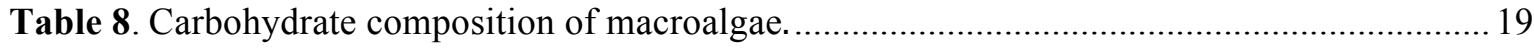

Table 9. Composition of different seaweed species and selected lignocellulosic feedstocks..........20

Table 10. Methane yields and conversions efficiencies for different macroalgae (based on

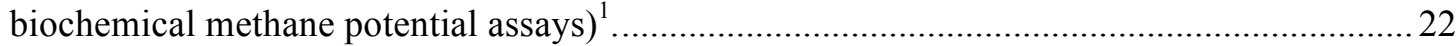

Table 11. Biodiesel from Green Macroalgae (Chaetomorpha linum) ..........................................22

Table 12. Seaweed yields and production costs from marine biomass. ........................................ 24

Table 13. Process assumptions for macroalgae methane digestion................................................2 26

Table 14. Estimated production and cost for biofuels conversion from seaweed ${ }^{\mathrm{a}}$ (Reith et al. 2005). .28

Table 15. Fuel product cost results (2008 annual average dollars) .............................................29

Table 16. Resource consumption data for macroalgae fuel (Bastianoni et al., 2008)..................... 35 


\subsection{Introduction}

The Energy Independence and Security Act of 2007 (EISA) mandates the increased supply of alternative fuels meeting the Renewable Fuel Standard. This requires fuel sold in the U.S. to contain a minimum of 36 billion gallons of renewable fuels, including advanced and cellulosic bio-fuels by 2022 . The U.S. Department of Energy (DOE) has set a goal in its Strategic Plan to promote energy diversity and independence. In particular, the DOE Energy Efficiency and Renewable Energy (EERE) Biomass Program supports four key priorities: 1) reduce dependence on foreign oil, 2) promote diverse, sustainable, domestic energy resources, 3) reduce carbon emissions and 4) establish a domestic biomass industry (EERE, 2010)

Meeting the EISA renewable fuels goals requires development of a large sustainable supply of diverse biomass feedstocks from across the country. Macroalgae could be a potential contributor towards this goal. This resource would be grown in marine waters and would not compete with existing land-based energy crops. The amounts of macroalgae that could be available as a biomass feedstock are potentially high, but very little analysis has been done on this resource. This project provides information needed to assess the development of macroalgae as a feedstock for the biofuels industry.

Attention is currently turning to the use of marine biomass to supplement terrestrial biomass as a source of feedstock for biofuel production, and macroalgae are under consideration as a candidate algal feedstock. Macroalgae, commonly referred to as seaweeds, are multi-cellular, photosynthetic organisms. They are evolutionarily diverse and abundant in the world's oceans and coastal waters. They have a low lipid content as a general rule and are high in carbohydrates that can be converted to various gas and liquid fuels. Early efforts established the economic feasibility of anaerobic digestion for conversion of macroalgae to methane (Chynoweth et al., 2001), whereas the conversion technology for production of liquid transportation fuels from macroalgae is at a very early stage. Additionally, the production of macroalgae feedstock at the scale needed to supply a fuels economy has many uncertainties that remain to be addressed.

There is already a commercial market for macroalgae, mainly as food or as feedstock for polysaccharide and hydrocolloid extraction, which is relatively small when compared with the scale of cultivation needed for macroalgae to be considered a significant contributor to the biomass needed to meet EISA production goals. However, the resource potential is high, and the ability of the world's oceans to produce marine biomass as a biofuel feedstock supply is largely untapped (Roesijadi et al., 2008). To achieve this potential would require cultivation at levels much higher than is currently conducted and technological innovation in cultivation technology to produce marine biomass at the needed scale. New production in environments not currently utilized for macroalgae farming would be needed to minimize the creation of competing demands on existing supplies.

The United States does not currently have an industry for producing macroalgae; thus, domestic utilization of macroalgae products is largely dependent on supply from foreign sources. The establishment of a de novo macroalgae biomass production industry in the United States could result in competing demands with other uses of marine waters, e.g., commercial, recreational, marine preserves, or military, and this topic will need further evaluation. On the other hand, unlike other parts of the world where macroalgae production industries already exist, creation of a macroalgae-based biofuels industry in the 
United States would not compete with an existing domestic supply chain for food or other commercial products, nor would it divert current production to a novel biofuels market. The development of a macroalgae-based biofuels industry will also require technology development for the conversion of novel macroalgal biochemical constituents to liquid transportation fuels with the performance characteristics and infrastructure requirements of current hydrocarbon-based products.

Preliminary feasibility analysis has recently been conducted by groups in the Netherlands (Reith et al., 2005), U.S.A. (Roesijadi et al., 2008), and Ireland (Bruton et al., 2009). Consideration of macroalgae is included in a recent report by the International Energy Agency (IEA-Bioenergy, 2010) and the U.S. Department of Energy's roadmap for algal biofuels (U.S.DOE, 2010). Pilot efforts are now underway in both Asia and Europe for development of macroalgae as a biofuels feedstock.

This report is an initial assessment of the status of macroalgae as a feedstock for biofuels production. Of interest are the following topic areas:

- Species of macroalgae to be used as feedstock and competing uses

- Level of international interest in macroalgae as biomass feedstock

- Preliminary resource assessment

- Types of biofuels and conversion technology appropriate for macroalgae

- Preliminary economic considerations associated with the cost of production.

- Preliminary Life Cycle Analysis (LCA) literature review. 


\subsection{Characteristics of Macroalgae}

Macroalgae represent a diverse group of eukaryotic, photosynthetic marine organisms. Unlike microalgae, which are unicellular, the macroalgal species are multicellular and possess plant-like characteristics. They are typically comprised of a blade or lamina, the stipe, and holdfast for anchoring the entire structure to hard substrates in marine environments (Figure 1). The general features of these structures are very diverse in the various taxa comprising macroalgae (Figure 1). There are forms whose primary feature is that of long blades, forms that are branched, and others that are leafy and form mats. Moreover, some forms possess air bladders that act as flotation devices that enable some species to stand upright or occur free-floating on ocean surfaces.

\section{A. Saccharina latissima.}

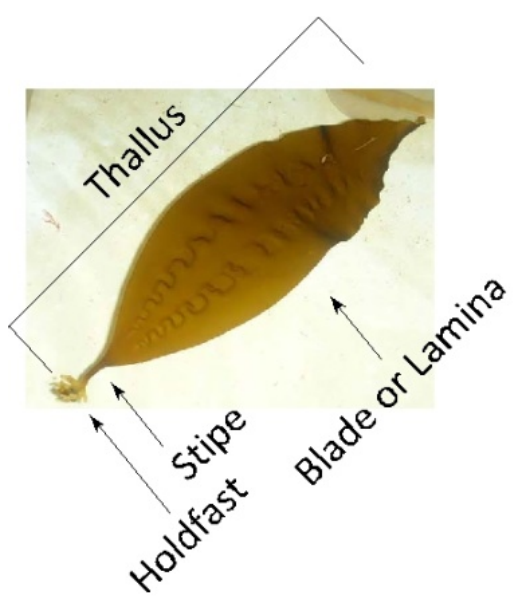

B. Ascophyllum nodosum

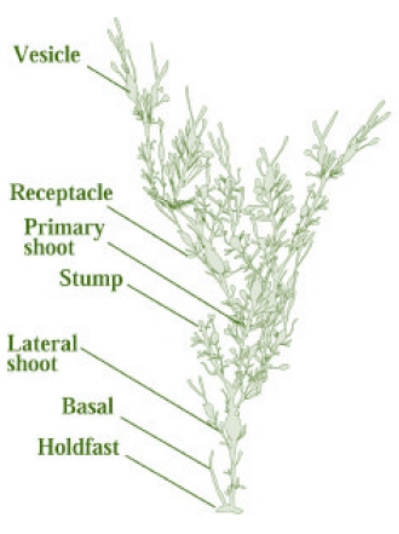

C. Ulva lobata

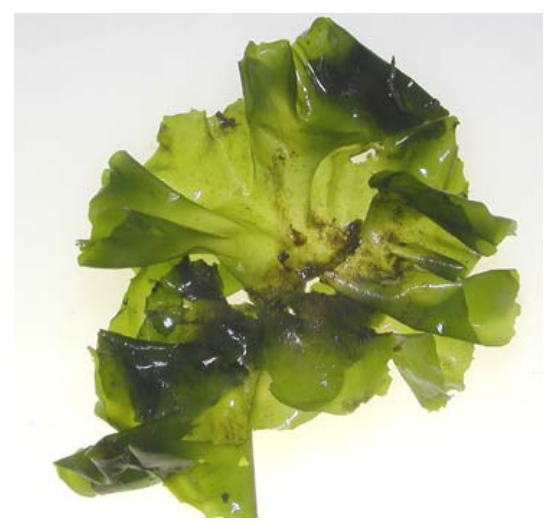

Figure 1. The gross morphology of a young Saccharina latissima, a kelp (http://depts.washington.edu/fhl/mb/Sacc lat_Mego/DSCN4990.jpg); Ascophyllum nososum, a fucoid brown alga (Ugarte et al., 2001); and Ulva lobata (http://www.solpugid.com/cabiota/ulva_lobata.jpg), a leafy green alga.

Macroalgae are classified as Phaeophyta or brown algae, Rhodophyta or red algae, and Chlorophyta or green algae based on the composition of photosynthetic pigments. The green macroalgae have evolutionary and biochemical affinity with higher plants.

The life cycles of macroalgae are complex and diverse, with different species displaying variations of annual and perennial life histories, combinations of sexual and asexual reproductive strategies, and alternation of generations (Figure 2). 


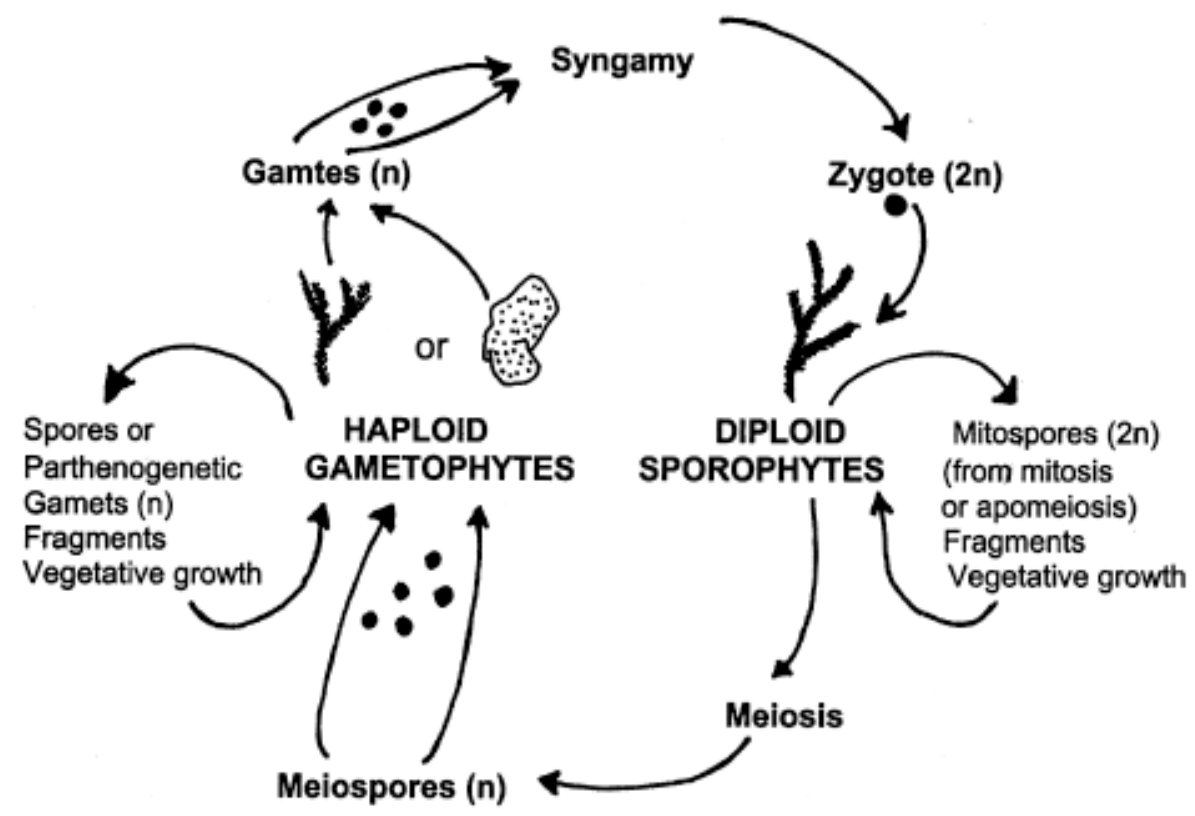

Figure 2. Generic representation of alternating life cycle of seaweeds (Collado-Vides, 2001)

Each species has its characteristic life history strategy, which must be understood and brought under control in order to develop appropriate cultivation techniques. The successful cultivation of commercially important seaweeds such as Laminaria and Porphyra in Asia was possible after life cycles were first understood, brought under control, and incorporated into protocols to produce seed in nursery operations (Tseng, 1987; Choi et al., 2002). Today, most of the commercial harvest of macroalgae for food and other products comes from cultivated algae derived from hatchery propagated seed stock, rather than from harvest of natural stands.

The distribution of macroalgae is worldwide. They are abundant in coastal environments, primarily in nearshore coastal waters with suitable substrate for attachment. Macroalgae also occur as floating forms in the open ocean, and floating seaweeds are considered one of the most important components of natural materials on the sea surface (Vandendriessche et al., 2006). As will be discussed later, this distribution has implications in the consideration of sites for macroalgal production as a biofuels feedstock. 


\subsection{Current Macroalgae Industry}

Macroalgae have a commercial market as both a food product and for their biochemical constituents. Food products for human consumption, mainly associated with the Asian market, account for 83 to $90 \%$ of the total value of macroalgae (Table 1). Chemical products extracted from macroalgae account for most of the remaining value. The various species possess high levels of structural polysaccharides of commercial value. These include alginate from brown algae and agar and carrageenan from red algae. Other uses include fertilizer, soil conditioners and animal feed for agriculture. During World War I, the California kelp Macrocystis pyrifera was harvested for production of potash and acetone for manufacture of gunpowder, a significant but short-lived industry (Neushul, 1989). The global monetary value of $\$ 6$ billion in 2003 (Table 1) had increased to over \$7.1 billion in 2006 (Table 2). The use of macroalgae as a commercial feedstock for fuels production, however, is currently nonexistent. Thus, production of macroalgae for conversion to fuels would represent a new market area, currently undeveloped worldwide.

Table 1. Estimated global value of seaweed products per annum as reported 2003 (McHugh, 2003).

$\begin{array}{ll}\text { Product } & \text { Value }\end{array}$

Human Food (Nori, aonori, kombu, wakame, etc.)

$\$ 5$ billion

Algal hydrocolloids

- Agar (Food ingredient, pharmaceutical, biological/microbiological)

$\$ 132$ million

- Alginate (Textile printing, food additive, pharmaceutical, medical)

\$213 million

- Carrageenan (Food additive, pet food, toothpaste)

\$240 million

Other uses of seaweeds

- Fertilizers and conditioners

\$5 million

- Animal Feed

$\$ 5$ million

- Macroalgal Biofuels

Total

$\$ 5.5-6$ billion

Harvest of wild stock accounted for about 1.1 million wet metric tons of the annual world macroalgae production in 2006, while aquaculture accounted for about 15.1 million wet metric tons of the annual production (Table 2), outpacing that of wild harvests by over ten-fold. Annual production associated with harvest of wild stock was more evenly distributed worldwide than production from aquaculture. Whereas the top ten countries harvesting wild stocks included countries in Asia, South America, Central America, Europe, and Iceland, plus Russia, and Australia, production from aquaculture was centered in Asia and dominated by China, which accounted for $72 \%$ of the total production and $73 \%$ of the total value of cultured macroalgae. The other top ten countries for macroalgae aquaculture accounted for $99 \%$ of the remaining aquaculture-based production. Monetary values for aquaculture products, which averaged about $\$ 477$ USD per wet metric ton (Table 2), reflected the dominance of Chinese production. 
Table 2. World production (wet metric ton) of wild stock harvest and cultured macroalgae plus monetary value of cultured (USD) in 2006 by country (FAO, 2008a).

\begin{tabular}{|c|c|c|c|c|c|c|c|}
\hline \multicolumn{3}{|c|}{ Harvests of wild stock } & \multicolumn{5}{|c|}{ Aquaculture } \\
\hline Source & $\begin{array}{l}\text { Production } \\
\text { (metric ton) }\end{array}$ & $\begin{array}{l}\% \text { of } \\
\text { Total } \\
\end{array}$ & Source & $\begin{array}{l}\text { Production } \\
\text { (metric ton) }\end{array}$ & $\begin{array}{l}\% \text { of } \\
\text { Total } \\
\end{array}$ & $\begin{array}{c}\text { Value } \\
\text { US } \$ 1,000 \mathrm{~s}\end{array}$ & $\$ /$ metric ton \\
\hline $\begin{array}{l}\text { World } \\
\text { total }\end{array}$ & $1,143,273$ & 100.00 & World total & $15,075,612$ & 100.00 & $7,187,125$ & 476.74 \\
\hline China & 323,810 & 28.32 & China & $10,867,410$ & 72.09 & $5,240,819$ & 482.25 \\
\hline Chile & 305,748 & 26.74 & Philippines & $1,468,905$ & 9.74 & 173,963 & 118.43 \\
\hline Norway & 145,429 & 12.72 & Indonesia & 910,636 & 6.04 & 127,489 & 140.00 \\
\hline Japan & 113,665 & 9.94 & $\begin{array}{l}\text { Republic of } \\
\text { Korea }\end{array}$ & 765,595 & 5.08 & 269,657 & 352.22 \\
\hline Russian Fed & 65,554 & 5.73 & Japan & 490,062 & 3.25 & $1,051,361$ & $2,145.36$ \\
\hline Ireland & 29,500 & 2.58 & Korea DPRp & 444,300 & 2.95 & 244,365 & 550.00 \\
\hline Mexico & 27,000 & 2.36 & Chile & 33,586 & 0.22 & 52,394 & $1,560.00$ \\
\hline Iceland & 20,964 & 1.83 & Malaysia & 30,000 & 0.20 & 4,500 & 150.00 \\
\hline France & 19,160 & 1.68 & Vietnam & 30,000 & 0.20 & 15,000 & 500.00 \\
\hline Australia & 15,504 & 1.36 & Cambodia & 16,000 & 0.11 & 4,000 & 250.00 \\
\hline Morocco & 14,870 & 1.30 & China, Taiwan & 5,949 & 0.04 & 447 & 75.14 \\
\hline Korea Rep & 13,754 & 1.20 & India & 4,668 & 0.03 & 467 & 100.04 \\
\hline Canada & 11,313 & 0.99 & Kiribati & 3,900 & 0.03 & 156 & 40.00 \\
\hline Indonesia & 9,830 & 0.86 & South Africa & 3,000 & 0.02 & 1,265 & 421.67 \\
\hline South Africa & 6,600 & 0.58 & $\begin{array}{l}\text { Russian } \\
\text { Federation }\end{array}$ & 818 & 0.01 & 982 & $1,200.49$ \\
\hline USA & 6,238 & 0.55 & Tanzania & 320 & 0.00 & 64 & 200.00 \\
\hline Madagascar & 5,300 & 0.46 & Solomon Is & 120 & 0.00 & 6 & 50.00 \\
\hline Peru & 3,434 & 0.30 & Fiji Islands & 119 & 0.00 & 65 & 546.22 \\
\hline Italy & 1,400 & 0.12 & Mali & 90 & 0.00 & 3 & 33.33 \\
\hline Ukraine & 1,121 & 0.10 & Namibia & 70 & 0.00 & 65 & 928.57 \\
\hline Portugal & 765 & 0.07 & France & 45 & 0.00 & 16 & 355.56 \\
\hline Spain & 485 & 0.04 & Mozambique & 15 & 0.00 & 23 & $1,533.33$ \\
\hline Estonia & 394 & 0.03 & Burkina Faso & 2 & 0.00 & 1 & 500.00 \\
\hline Tonga & 356 & 0.03 & St Lucia & 1 & 0.00 & 16 & $16,000.00$ \\
\hline Fiji Islands & 350 & 0.03 & Spain & 1 & 0.00 & 1 & $1,000.00$ \\
\hline Philippines & 314 & 0.03 & & & & & \\
\hline New Zealand & 225 & 0.02 & & & & & \\
\hline China, Taiwan & 190 & 0.02 & & & & & \\
\hline
\end{tabular}

Aquaculture-based production of macroalgae has been focused mainly on the genus Laminaria (reclassified as Saccharina for some species), Undaria, Porphyra, Euchema, and Gracilaria (Table 3). These five genera represented $76 \%$ of the total tonnage for cultured macroalgae. China was the greatest producer for all groups except Euchema, having a combined production of 7.9 million wet metric tons for the other four genera. The Philippines accounted for $91 \%$ of the 1.26 million wet-metric-ton aquaculture production of Euchema. The total monetary value of aquaculture production in Table 2 for 2006 reflects growth over that reported in 2003 for the entire seaweed industry (McHugh, 2003).

It is worthwhile to note that the United States contributes only marginally to the production of macroalgae and is not listed as a producer by FAO (FAO, 2008a). In the United States, the supply of macroalgae for human consumption and production of hydrocolloids is dependent on imports from producing countries. 
Table 3. World-wide farmed seaweed production (wet metric ton) in 2004 by taxa (adapted from Roesijadi et al., 2008).

\begin{tabular}{|c|c|c|c|c|}
\hline Taxa & Common name & Country & Metric ton & $\begin{array}{l}\text { Subtotal } \\
\text { by Taxa }\end{array}$ \\
\hline Laminaria japonica $^{I}$ & Japanese kelp & China & $4,005,640$ & \\
\hline Laminaria japonica & Japanese kelp & Democratic People's Republic of Korea, & 444,295 & \\
\hline Laminaria japonica & Japanese kelp & Japan & 47,256 & \\
\hline Laminaria japonica & Japanese kelp & Republic of Korea & 22,510 & $4,519,701$ \\
\hline Plantae aquaticae ${ }^{2}$ & Aquatic plants & China & $2,535,130$ & \\
\hline Plantae aquaticae & Aquatic plants & Malaysia & 30,957 & \\
\hline Plantae aquaticae & Aquatic plants & Cambodia & 16,840 & \\
\hline Plantae aquaticae & Aquatic plants & Japan & 15,968 & \\
\hline Plantae aquaticae & Aquatic plants & China & 3,230 & \\
\hline Plantae aquaticae & Aquatic plants & South Africa & 2,750 & \\
\hline Plantae aquaticae & Aquatic plants & Republic of Korea & 142 & \\
\hline Plantae aquaticae & Aquatic plants & Mali & 90 & $2,605,107$ \\
\hline Undaria pinnatifida & Wakame & China & $2,196,070$ & \\
\hline Undaria pinnatifida & Wakame & Republic of Korea & 261,574 & \\
\hline Undaria pinnatifida & Wakame & Japan & 62,236 & \\
\hline Undaria spp. & Wakame & France & 25 & $2,519,880$ \\
\hline Porphyra tenera & Laver (Nori) & China & 810,170 & \\
\hline Porphyra tenera & Laver (Nori) & Japan & 358,929 & \\
\hline Porphyra tenera & Laver (Nori) & Republic of Korea & 228,554 & \\
\hline Porphyra tenera & Laver (Nori) & Taiwan Province of China & 7 & $1,397,660$ \\
\hline Eucheuma cottonii $^{3}$ & Zanzibar weed & Philippines & $1,069,599$ & \\
\hline Eucheuma spp. & Eucheuma seaweeds & China & 97,820 & \\
\hline Eucheuma denticulatum & Spiny eucheuma & Philippines & 85,754 & \\
\hline Eucheuma spp. & Eucheuma seaweeds & United Republic of Tanzania, & 6,000 & \\
\hline Eucheuma spp. & Eucheuma seaweeds & Kiribati & 3,904 & \\
\hline Eucheuma cottonii & Zanzibar weed & Tonga & 1,195 & \\
\hline Eucheuma spp. & Eucheuma seaweeds & Solomon Islands & 120 & \\
\hline Eucheuma spp. & Eucheuma seaweeds & Fiji Islands & 45 & \\
\hline Eucheuma spp. & Eucheuma seaweeds & Saint Lucia & 1 & \\
\hline Eucheuma spp. & Eucheuma seaweeds & Federated States of Micronesia & 0 & $1,264,438$ \\
\hline Gracilaria verrucosa & Warty gracilaria & China & 888,870 & \\
\hline Gracilaria spp. & Gracilaria seaweeds & Viet Nam & 30,000 & \\
\hline Gracilaria spp. & Gracilaria seaweeds & Chile & 19,714 & \\
\hline Gracilaria verrucosa & Warty gracilaria & Taiwan Province of China & 9,085 & \\
\hline Gracilaria spp. & Gracilaria seaweeds & Philippines & 389 & \\
\hline Gracilaria spp. & Gracilaria seaweeds & South Africa & 95 & \\
\hline Gracilaria verrucosa & Warty gracilaria & Taiwan Province of China & 72 & \\
\hline Gracilaria spp. & Gracilaria seaweeds & Namibia & 67 & 948,292 \\
\hline Rhodophyceae & Red seaweeds & Indonesia & 397,964 & \\
\hline Rhodophyceae & Red seaweeds & Indonesia & 12,606 & 410,570 \\
\hline Sargassum fusiforme & Fusiform sargassum & China & 131,680 & 131,680 \\
\hline Kappaphycus alvarezii & Elkhorn sea moss & Philippines & 44,814 & \\
\hline Kappaphycus alvarezii & Elkhorn sea moss & Mozambique & 92 & 44,906 \\
\hline Phaeophyceae & Brown seaweeds & Republic of Korea & 22,814 & \\
\hline Phaeophyceae & Brown seaweeds & Russian Federation & 216 & 23,030 \\
\hline Monostroma nitidum & Green laver & Republic of Korea & 11,514 & 11,514 \\
\hline Caulerpa spp. & Caulerpa seaweeds & Philippines & 4,252 & 4,252 \\
\hline Enteromorpha prolifera & Dark green nori & China & 3,280 & 3,280 \\
\hline Gelidium amansii & Japanese isinglass & China & 1,150 & 1,150 \\
\hline Asparagopsis spp. & Harpoon seaweeds & France & 12 & 12 \\
\hline TOTAL & & & $13,885,497$ & $13,885,497$ \\
\hline
\end{tabular}

Note: ${ }^{1}$ Reclassified as Saccharina japonica, ${ }^{2}$ Plantae aquaticae is a designation for unidentified aquatic plant per FAO terminology, ${ }^{3}$ Reclassified as Kappaphycus alvarezii. 


\subsection{Preliminary Resource Assessment for Macroalgal Production in the United States}

For the United States, the production of macroalgae at any significant scale will be a novel endeavor and require the identification of suitable sites for siting macroalgal production facilities. This preliminary assessment is focused on the scale of sea surface needed for cultivation of macroalgae to sustain a biofuels market.

The resource under consideration for siting macroalgal cultivation is all the marine waters of the U.S. Territorial Sea and the broader U.S. Exclusive Economic Zone (EEZ). The Territorial Sea of the United States is a zone extending 12 nautical miles, i.e., $22.224 \mathrm{~km}$, from the baselines of the United States over which it exercises sovereignty and jurisdiction (Proclamation 5928 in U.S. Department of State Bulletin, March, 1989). Its EEZ (Figure 3), over which it has rights to minerals and marine resources, generally extends to 200 nautical miles, i.e., $370.4 \mathrm{~km}$, beyond the territorial sea. The surface area of the U.S. EEZ of $11,661,786 \mathrm{~km}^{2}$ is the largest of all countries.

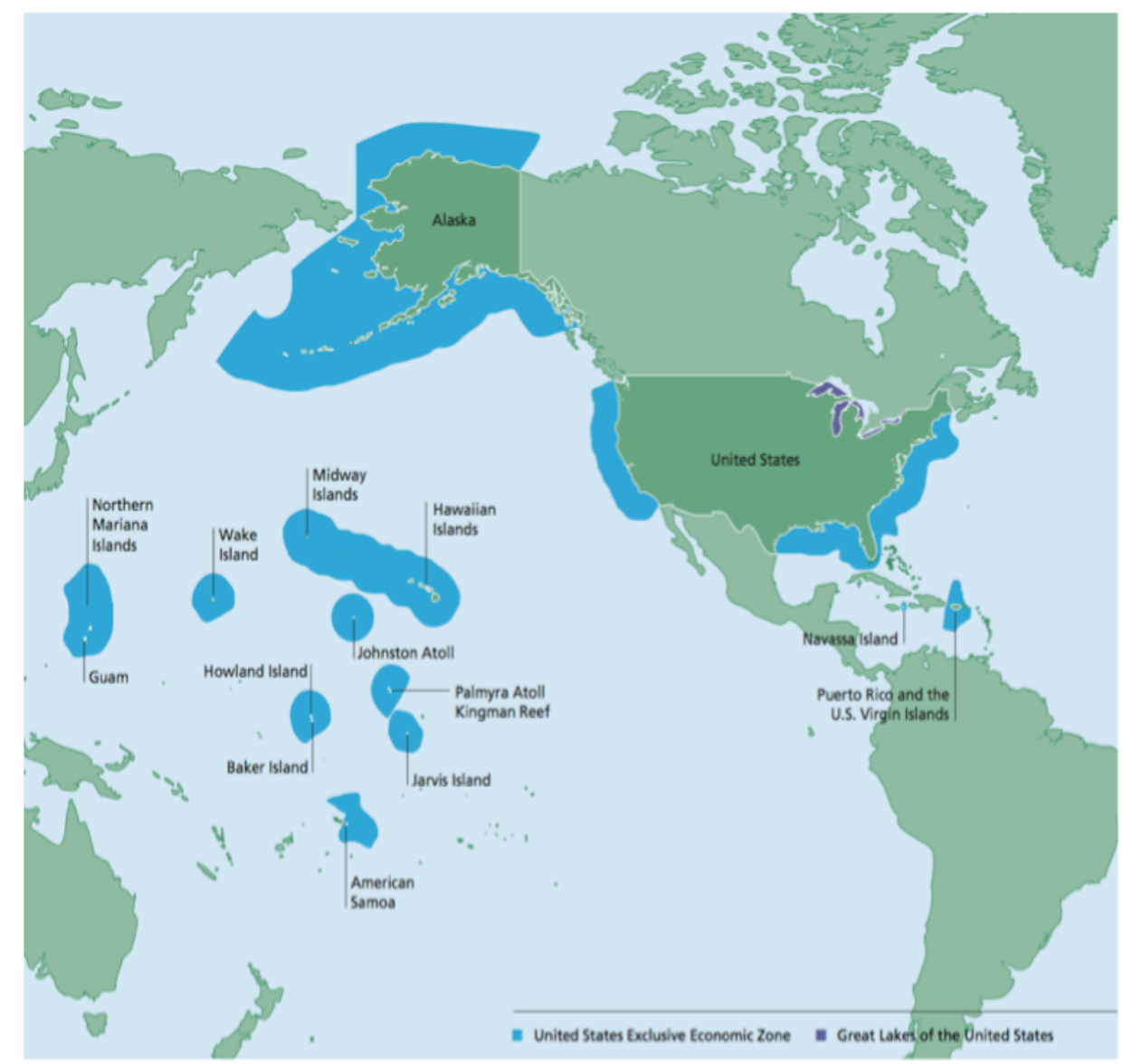

Figure 3. U.S. Exclusive Economic Zone (http://aquaculture.noaa.gov/pdf.20_eezmap.pdf). 
Because of increased competition for use of nearshore coastal sites, the development of offshore aquaculture in the U.S. EEZ is gaining interest (Goldburg et al., 2001). Locating this activity in the EEZ would result in access to better water quality, limited conflict with coastal land users, and independence from local and state jurisdiction (Goldburg et al., 2001). By extending the notion of offshore aquaculture to include farming for marine biomass, the area contained within the Territorial Sea and EEZ become the totality of ocean surface available to locate macroalgae cultivation facilities in U.S waters. Locations where nutrient-rich upwelling zones exist are of particular interest (Roesijadi et al., 2008). Specific areas for siting cultivation facilities and land-based support infrastructure have yet to be identified.

Estimates for macroalgae production in the analysis below are based on an average production of 2960 dry metric ton $/ \mathrm{km}^{2} / \mathrm{yr}$ (calculated from Roesijadi et al., 2008; Bruton et al., 2009; Oilgae, 2010). Table 4 shows the estimated scale of macroalgae production needed to meet specified goals. For example, the DOE Biomass Program Multi-Year Program Plan (MYPP (EERE, 2010)) for biomass feedstock specifies production targets of 130 million dry metric tons per year of biomass by 2012 and 250 million dry metric tons per year by 2017. Using only macroalgae to meet these biomass targets would require cultivation on about 44,000 and $84,500 \mathrm{~km}^{2}$, respectively, which correspond to 0.4 and $0.7 \%$ of the U.S. EEZ (Table 4).

Table 4. Area and percent of EEZ needed to meet MYPP (EERE, 2010) target using marine biomass (estimated using an average production estimate of 2,960 dry metric ton $\left./ \mathrm{km}^{2} / \mathrm{yr}\right)^{1}$.

\begin{tabular}{lccc}
$\begin{array}{l}\text { MYPP } \\
\text { target year }\end{array}$ & $\begin{array}{c}\text { Biomass target } \\
\text { (million dry metric ton) }\end{array}$ & $\begin{array}{c}\text { Area Needed } \\
\left.\mathbf{( k m}^{2}\right)\end{array}$ & $\begin{array}{c}\text { Percent of } \\
\text { U.S. EEZ }\end{array}$ \\
\hline 2012 & 130 & 43919 & $0.4 \%$ \\
2017 & 250 & 84459 & $0.7 \%$ \\
\hline
\end{tabular}

Note: ${ }^{1}$ Average of values from Roesijadi et al (2008), Oilgae (2010), and Bruton et al (2009).

While it is not suggested that marine biomass can be used to meet $100 \%$ of the MYPP biomass targets, the production potential in the U.S. EEZ suggests that the feasibility of marine biomass as a complementary biomass source should receive serious consideration. Oilgae (2010), using a production figure of 5,000 dry metric ton per year, estimated that macroalgae grown on $15,000 \mathrm{~km}^{2}$ is needed to replace $1 \%$ of worldwide gasoline consumption. By applying a more conservative estimate of 2,960 dry metric ton $/ \mathrm{km}^{2} / \mathrm{yr}$ and correcting worldwide gasoline consumption for the $43 \%$ attributed to the U.S. (GAO, 2005), it is estimated that replacement of $1 \%$ of gasoline usage by the U.S. with macroalgae could be achieved with cultivation on $10,895 \mathrm{~km}^{2}$ or $0.09 \%$ of the U.S. EEZ (Table 5). One percent of the total U.S. gasoline consumption in 2008 (EIA, 2008) corresponds to 3,780,000 gallons/day and macroalgal gasoline equivalents of $347 \mathrm{gal} / \mathrm{km}^{2} /$ day (Table 5).

Table 5. Macroalgal production and gasoline equivalents to meet a 1\% US gasoline displacement target.

\begin{tabular}{lccccc}
\hline $\begin{array}{l}\text { Area required } \\
\text { for 1\% U.S. gas } \\
\text { use }\left(\mathbf{k m}^{\mathbf{2}}\right)\end{array}$ & $\begin{array}{c}\text { \% of } \\
\text { U.S. }\end{array}$ & $\begin{array}{c}\text { Gasoline } \\
\text { Equivalents } \\
\text { (gal/km } / \mathbf{d a y})\end{array}$ & $\begin{array}{c}\text { Annual required } \\
\text { production } \\
\text { (dry metric ton) }\end{array}$ & $\begin{array}{c}\text { Current } \\
\text { Commercial } \\
\text { Production } \\
\text { (dry metric ton) }\end{array}$ & $\begin{array}{c}\text { Required } \\
\text { Fold-increase } \\
\text { in production }\end{array}$ \\
\hline 10,895 & 0.09 & 347 & 32.3 million & 3.0 million & 10.7 \\
\hline
\end{tabular}

Note: ${ }^{1}$ Converted to dry metric tons from wet metric tons (see Table 2 ) using $80 \%$ water content. 
With a macroalgae production rate of 2,960 dry metric ton $/ \mathrm{km}^{2} / \mathrm{yr}$, the annual production on $10,895 \mathrm{~km}^{2}$ of ocean surface would be 32.3 million dry metric ton. The United States would have to produce about 10.7 times the current level of worldwide commercial production to replace $1 \%$ of its gasoline consumption.

The range of production used to calculate the average production above is considerable, from a low of 1000 to a high of 6000 dry metric ton $/ \mathrm{km}^{2} / \mathrm{yr}$. Improvement in cultivation technology that would yield higher rates of production could lead to much more favorable prospects for large-scale macroalgal cultivation for biofuel production than that derived from the current average rate. For example, novel experimental cultivation systems being developed in Ireland for the macroalgae products industry can be extrapolated to production levels of 8,000 to 16,000 dry metric ton $/ \mathrm{km}^{2} / \mathrm{yr}$ if scaled up using a multi-tier cultivation system (Kraan, 2010), which are considerably higher than that used for estimates described above. Advances in macroalgal cultivation technology could potentially increase production from three to 10 -fold with a corresponding decrease in the area needed for cultivation to meet specified production goals. 


\subsection{Past and Current Activities in Macroalgal Biofuels}

Technologies available for conversion of biomass to fuels have been applied to macroalgae in limited ways. There is reason to suggest that fermentation of the California kelp Macrocystis pyrifera to produce acetone during World War I (Neushul, 1989) also resulted in butanol formation. Butanol has properties of energy density, low corrosivity, hydrophobicity, and ability to blend with gasoline, considered desirable in an advanced biofuel (Brekke, 2007) so is of current interest.

The Marine Biomass Program of the 1970's and early 1980's (Bird et al., 1987) examined anaerobic digestion of macroalgae and established the feasibility of converting Macrocystis to methane (Chynoweth et al., 2001). This program tested offshore growth structures deployed in deep waters off the coast of Southern California for cultivation of the kelp. While it was determined that such structures could support growth, the technology of that time was not sufficiently developed to overcome challenges of open ocean

forces encountered in offshore environments and balance them with the engineering needed for successful operation. Efforts that addressed the feasibility of anaerobic digestion of macroalgae to methane as a path to biofuels production were more promising (Chynoweth et al., 1987). With Macrocystis as the macroalgal feedstock, anaerobic digestion to methane proceeded with $80 \%$ of the theoretical yield, and feedstock composition, particularly of mannitol, affected culture performance. The biochemical methane potential of Macrocystis was comparable to or exceeded those of terrestrial biomass and waste feedstocks, and the total energy potential of macroalgae was estimated to exceed that from all terrestrial sources by over three-fold (Chynoweth et al., 2001). At the conclusion of this program, the feasibility of producing methane from macroalgae was considered competitive with that from terrestrial biomass. However, the reliability of using large open-ocean, growth structures to provide the feedstock supply was inconclusive and mainly demonstrated the inadequacies of the technology of that time.

With the resurgence in interest in algal biofuels, attention has again turned to macroalgae as a possible biomass feedstock. The lessons learned from the Marine Biomass Program, plus experience gained through oil and gas exploration, oceanographic and atmospheric surveillance of ocean conditions and weather prediction, major improvements in tensile strength and weight of materials used at sea, and increased understanding of interactions between seaweed and support systems under realistic environmental conditions will be useful in assessing prospects for modern macroalgal cultivation as a biofuels feedstock. Efforts are now underway in both Asia and Europe to develop macroalgae as feedstock.

The Tokyo Gas Company working with the New Energy and Industrial Technology Development Organization of Japan used refuse seaweed collected from shorelines as feedstock to successfully demonstrate the production of electricity and heat from biogas derived from anaerobic digestion of macroalgae (Matsui et al., 2006). The biogas was mixed with city natural gas to power a gas engine power generator with a capacity of using one-metric ton macroalgae per day to provide the electricity and heat requirements of the production plant (Figure 4). Saccharina and Ulva were the macroalgal taxa used as feedstock in this demonstration. 


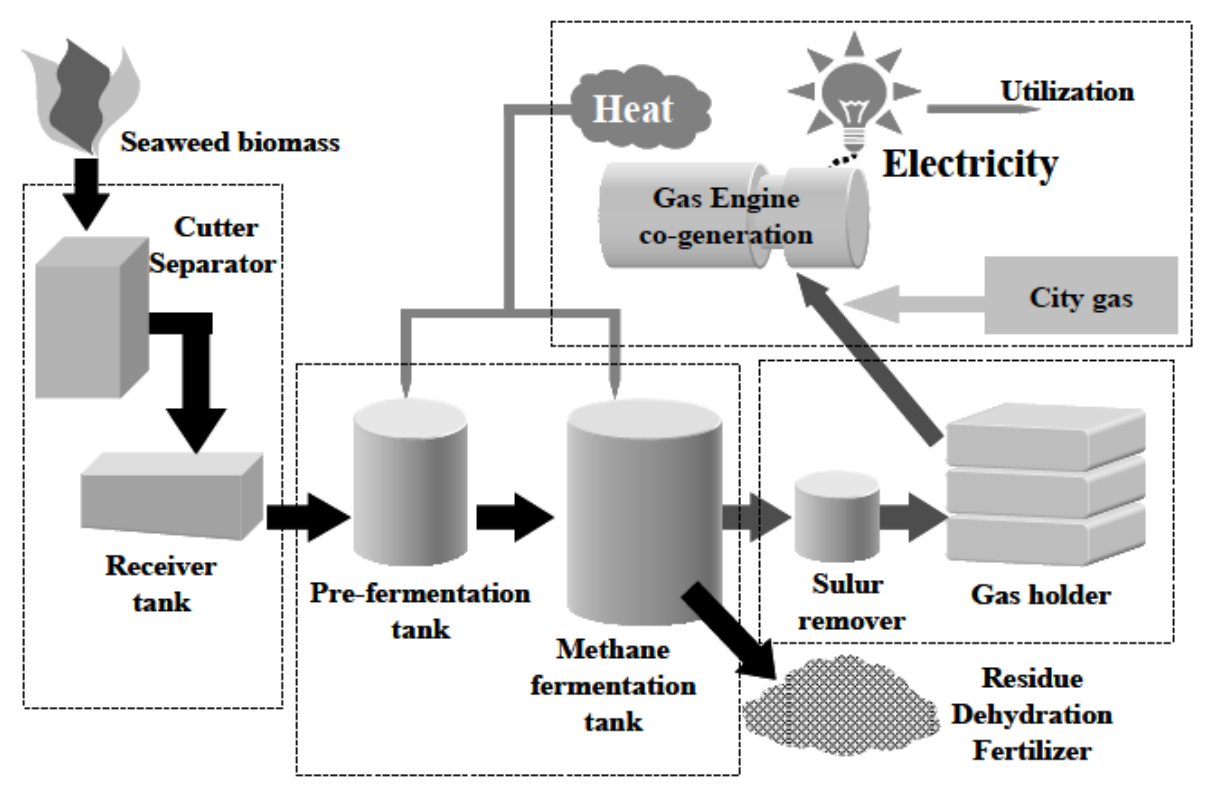

Figure 4. Seaweed processing plant for production of methane and electricity (Matsui et al., 2006).

The Mitsubishi Research Institute is leading an industry-academia consortium for research on bioethanol production from seaweed. Participants will study ethanol production using waste seaweed and improved technologies for culturing seaweed. Their plan is to start demonstration in 2012, develop seaweedculturing technologies by 2016, and establish a production process around 2020. Around 30 organizations will participate in the project, including such companies as Tsukishima Kikai and Mitsui Engineering \& Shipbuilding. (1 April 2008, Nikkei Sangyo Shimbun) (http://ukinjapan.fco.gov.uk/resources/en/pdf/5606773/200804news.pdf).

The Sunrise Project (Aizawa et al., 2007) describes a concept for open ocean cultivation of Sargassum using floating, tethered arrays deployed in the coastal waters of Japan.

Indonesia and South Korea have agreed to develop a seaweed-based biofuel based on the marine resources in coastal waters of Indonesia and Korea's advanced technological capabilities to convert seaweed to biofuels (http://www.thebioenergysite.com/news/3272/joint-effort-to-develop-biofuel-fromseaweed).

The Biomara Project, coordinated by the Scottish Association of Marine Sciences and co-sponsored by the European Union NTERREG IVA Programme, Highlands \& Islands ENTERPRISE, The Crown Estate, Northern Island Executive, and the Irish and Scottish governments, has as its aim demonstrating the "feasibility and viability of producing third generation biofuels from marine biomass". Several European institutions are currently investigating the production of macroalgae for conversion to methane and ethanol as part of this program. Prototypes for offshore growth of the kelp Laminaria hyperborea have been successfully tested in the North Sea (Buck et al., 2004a; Buck, 2005).

In the United States, the U.S. Department of Energy is supporting feasibility analyses through the Office of Energy Efficiency and Renewable Energy and research on production of butanol through its Advanced Research Projects Agency_Energy organization. 
Companies that are engaged in efforts to produce fuels from macroalgae recently compiled by Oilgae are listed below (Table 6).

Table 6. Companies currently engaged in macroalgae to fuels production ${ }^{1}$.

\begin{tabular}{|c|c|}
\hline Company & Activity \\
\hline Seaweed Energy Solutions ${ }^{2}$ & $\begin{array}{l}\text { Offshore cultivation and conversion to biogas and } \\
\text { bioethanol }\end{array}$ \\
\hline Green Gold Algae and Seaweed Sciences, Inc ${ }^{3}$ & Land-based ponds and conversion to ethanol \\
\hline $\begin{array}{l}\text { Butamax Advance Fuels-Dupont-BioArchitecture } \\
\text { Lab-Statoil }^{4}\end{array}$ & $\begin{array}{l}\text { Offshore kelp cultivation and conversion to ethanol } \\
\text { and butanol }\end{array}$ \\
\hline Seambiotic Ltd $^{5}$ & $\begin{array}{l}\text { Land-based ponds and } \mathrm{CO}_{2} \text { absorption of power } \\
\text { plant flue gases }\end{array}$ \\
\hline Oil Fox ${ }^{6}$ & Biodiesel from seaweed \\
\hline Blue Sun Energy ${ }^{7}$ & Jet fuel production \\
\hline Holmfjord $\mathrm{AS}^{8}$ & Biofuel production from seaweed \\
\hline \multicolumn{2}{|l|}{${ }^{\mathrm{C}}$ Adapted from Oilgae (2010) } \\
\hline \multicolumn{2}{|l|}{${ }^{2} \mathrm{http}: / /$ www.seaweedenergysolutions.com } \\
\hline \multicolumn{2}{|c|}{${ }^{3}$ http://www.gold-green.com/GGASS/Templates/showpage.asp?DBID=1\&LNGID=1\&TMID=10000\&FID=552 } \\
\hline \multicolumn{2}{|l|}{${ }^{4}$ http://www.butamax.com/; http://www.ba-lab.com/ } \\
\hline \multicolumn{2}{|l|}{${ }^{5} \mathrm{http}: / /$ www.seambiotic.com/ } \\
\hline \multicolumn{2}{|l|}{${ }^{6} \mathrm{http}: / /$ www.oilfox.com.ar/ } \\
\hline${ }^{7}$ http://www.gobluesun.com/index.php & \\
\hline${ }^{8}$ www.holmfjord.no & \\
\hline
\end{tabular}




\subsection{The Macroalgae-to-Market Supply Chain}

Supply chain considerations in taking macroalgae supply to market are summarized in Table 7. Technical aspects of this supply chain as well as preliminary economic analysis are discussed in the following sections. At the present time, because no such supply chain exists for macroalgae-to-biofuels market activity, considerations are based on existing activities associated with the current macroalgae aquaculture industry and research on relevant topics such as conversion of macroalgae to various potential fuel types. For economic analysis, data derived for other biomass sources were applied to analysis of macroalgae.

Table 7. Supply chain considerations (Bruton et al., 2009).

\begin{tabular}{llllll}
\hline Basic Research & Feedstock & Harvesting & Pretreatment & $\begin{array}{l}\text { Downstream } \\
\text { processing }\end{array}$ & Market \\
\hline Strain selection & Natural stock & Manual & Cleaning & Biogas & Economic analysis \\
Strain development & Aquaculture & Mechanized & Dewatering & Fermentation & Logistics \\
Growth optimization & Nearshore & & Desalination & Thermal conversion & Infrastructure \\
& Offshore & & & Residues & Engines \\
& Pond culture & & & & \\
\hline
\end{tabular}

\subsection{Cultivation}

The commercial market for seaweed products has driven the development of a seaweed cultivation industry centered mainly in Asia and in Chile. Almost 90\% of seaweed for human use comes from cultivation (Zemke-White et al., 1999), and four genera representing species of Laminaria (also Saccharina), Porphyra, Gracilaria, and Undaria comprise 93\% of the cultured seaweeds (Santelices, 1999).

Modern culture technology based on use of artificially-produced seed as a source of propagules is relatively recent (circa 1950s) and a direct result of research that brought the life cycle of key species such as Saccharina japonica, Porphyra yezoensis, and Gracilaria spp. under control. Typically, seed grown in greenhouses are attached to substrates, usually rope structures, then reared to plantlet size and transplanted to coastal farms for grow-out to harvestable size, an example of which is shown in Figure 5 for Laminaria japonica culture in China. 


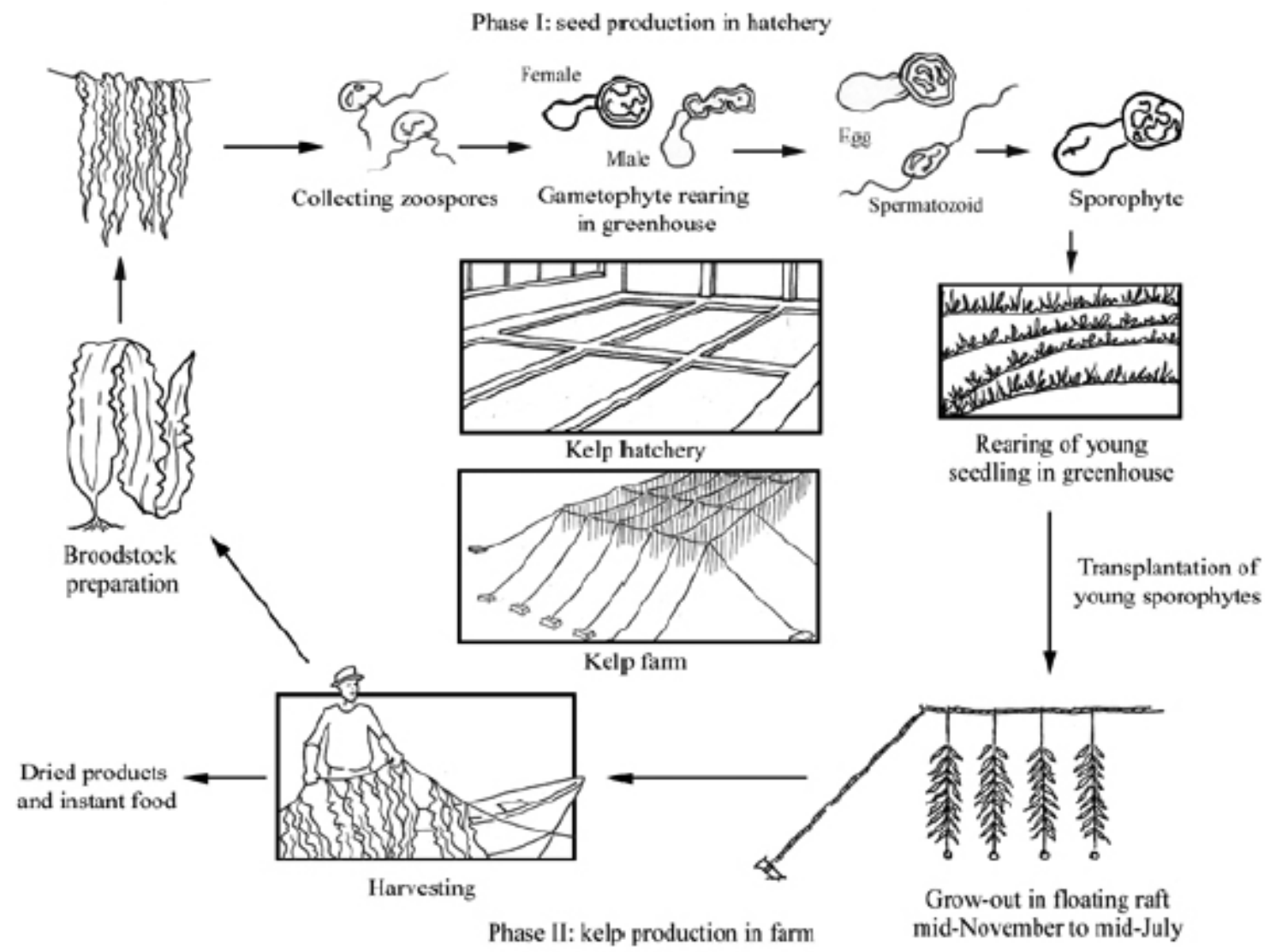

Figure 5. Production stages for the farming of Japanese kelp Laminaria japonica in China.

from http://www.fao.org/fishery/culturedspecies/Laminaria_japonica (FAO, 2008b).

The basic biology is sufficiently developed to enable current commercial culture production to meet the needs of the food and commodity markets. Additional environments will need to be identified for largescale cultivation of macroalgae for biofuels to minimize impacts on markets for current seaweed products through diversion of this production to biofuels. A massive increase in seaweed harvests, such as that needed to supply a biofuels market, has raised concerns that an overproduction of seaweed co-products can saturate specialty markets (Bruton et al., 2009). A major challenge lies in the selection of new environments that will support production of macroalgae at the scale needed to supply the biofuels market.

Options for siting macroalgal farms include offshore farms, nearshore coastal farms, and land-based ponds. The merits of each should be carefully evaluated, taking into consideration factors such as the scale of farms required to meet production needs, cost and availability of space and nutrients, environmental impacts, and competition with other uses. The co-siting of macroalgal farms with other structures such as windfarms (Buck et al., 2004b) and integrated aquaculture (Buck et al., 2006) have also been proposed as a way of leveraging other technologies to facilitate the cultivation of macroalgae. 
The operation of large offshore seaweed farms was initially tested by the Marine Biomass Program roughly three decades ago through several deployments of the kelp Macrocystis pyrifera on growth structures in deep waters off the coast of Southern California with artificially upwelled water as a nutrient source. As noted above, it was determined that such structures would support growth of kelp, but difficulties were encountered with the stability of either the structures or the stability of the attachment of kelp to the structures. The technology was not sufficiently developed to overcome offshore challenges of open ocean forces. Modern prototypes for offshore growth of the kelp Laminaria hyperborea have been successfully tested in the North Sea (Buck et al., 2004a; Buck, 2005), thus providing optimism for future technical efforts. However, the costs of such technologically-intensive systems are high (Reith et al., 2009).

Nearshore coastal environments are already used for macroalgae culture by countries like China, Japan, and Chile, which have viable seaweed aquaculture industries. Whether these countries can expand activities to the scale needed for the production of transportation fuels without adversely affecting food supplies remains to be determined. In the United States and Europe, environmental regulations and popular resistance against use of coastal regions for aquaculture represent barriers that will need to be overcome due to the conflicting uses of coastal zones.

Land-based pond systems as free-standing algal farms and in integrated aquaculture have also been considered for macroalgal cultivation (Hanisak, 1987; Friedlander, 2008). In the latter, wastes from coculture of other species would provide a nutrient supply for the macroalgae. Porphyra spp., Saccharina latissima, and Nereocystis luetkeana have been successfully cultured with salmonid fish species (Bruton et al., 2009). Advantages of the land-based systems over those in water have been listed as 1) ease of plant management; 2) use of plants with or without holdfast structures; 3) ease of nutrient application without dilution; 4) avoidance of open sea problems such as bad weather, disease, and predation; and 5) possibility of farm operations located in close proximity to conversion operations (Chynoweth, 2002). For contribution to a biofuels marketplace considerable scale-up from current activities, improvement in strain selection, and major technological improvements in efficiency of water movements and pond construction costs are needed (Friedlander, 2008). Pond culture of macroalgae is currently directed to specialty markets for seaweed products (see for example Acadian Seaplants, http://www.acadianseaplants.com).

\subsection{Harvest}

Seaweeds have been collected for their food and chemical constituents for centuries, and, until recently, harvesting natural populations has been the norm. With the advent of seaweed aquaculture, cultivated seaweeds are now the predominant source for human consumption. Currently, of the roughly 1.6 million dry metric tons of total seaweed harvested worldwide, about $90 \%$ is derived from cultivated sources (Roesijadi et al., 2008). Manual harvesting is common for both natural and cultivated seaweeds. Mechanized harvesting methods, which can involve mowing with rotating blades, suction, or dredging with cutters, have been developed. Invariably, such mechanized harvesters require boats or ships for operation. Harvesting methods based on mowing natural stands of Macrocystis pyrifera using mowers deployed from large ships (Figure 6) had already been developed in the early 1900s to supply a demand for seaweed derived acetone and potash (Whitney, 1987). The harvested seaweeds were pumped through a pipe directly onto adjacent barges, which were transported directly to a processing plant by tugboats. Modern seaweed harvesting vessels can be equipped with pumps to direct harvested seaweeds directly 
into nets or other containment structures (Ugarte et al., 2001). Application of mechanical harvesters in European seaweed operations have been described in a recent feasibility analysis for seaweeds as a biofuels feedstock in Ireland (Bruton et al., 2009).

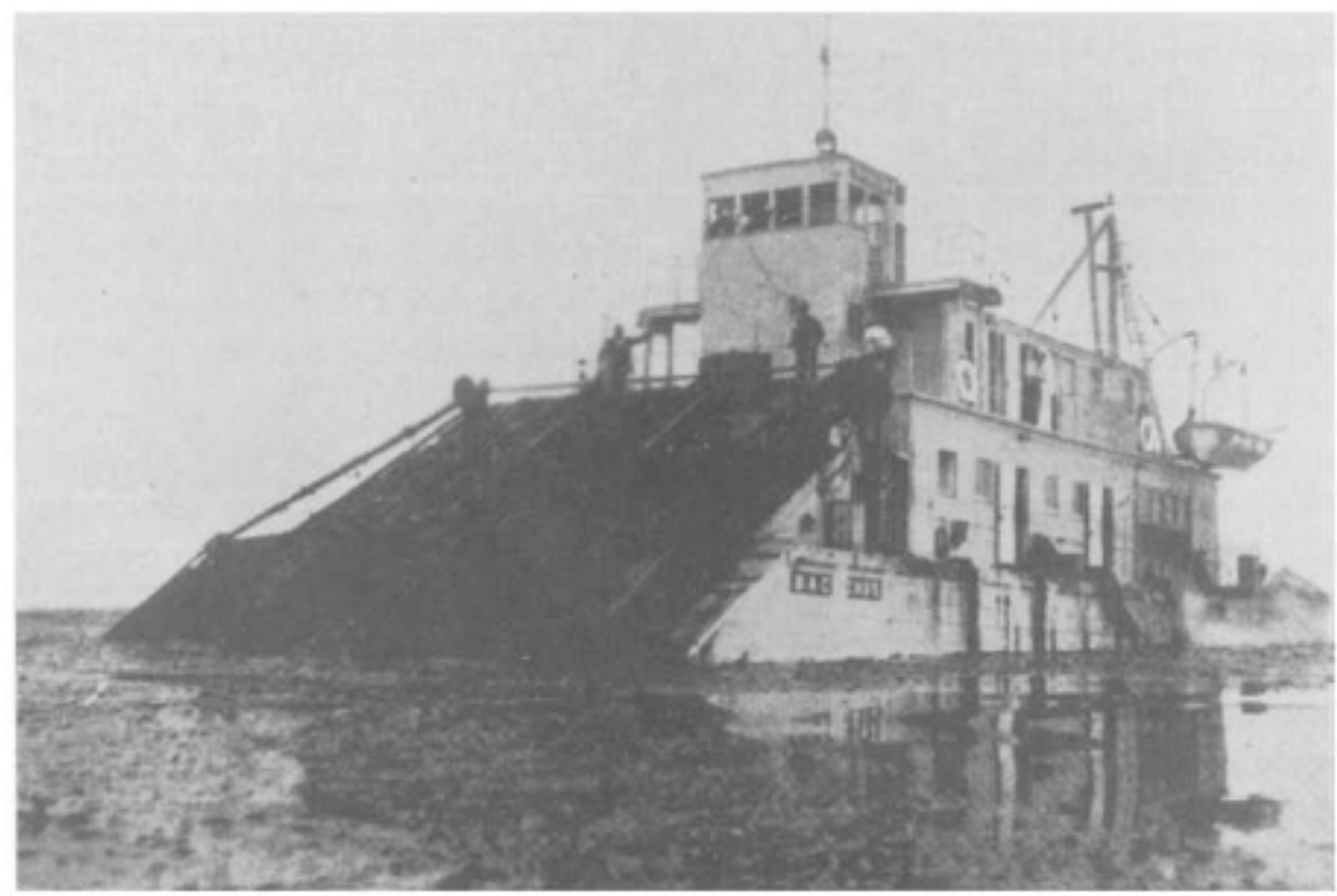

Figure 6. Hercules Powder Company's harvester, Bacchus (Whitney, 1987)

The concept of large offshore macroalgae farms and associated biorefineries has from the outset included mechanized harvesting techniques. In the Marine Biomass Program, sequential mowing and regrowth of the kelp Macrocystis pyrifera was envisioned as a means of sustainable harvest and replenishment of the feedstock supply. The exact nature of such mechanization will depend on the form of cultivation and form of algae being cultured. For example, attached forms that tend to stand upright, such as Macrocystis, may be amenable to mowing. Floating seaweeds such as Sargassum spp. in floating pens and low growing attached forms such as Gracilaria will require different approaches compatible with their growth characteristics. In forms such as Laminaria grown on off-shore rings (Buck et al., 2004a), harvesting may require retrieval of growth structures with attached seaweeds and transport to shore (Figure 7). Similarly, cultivation in land-based pond systems will require technology appropriate for that mode of cultivation. Mechanization will undoubtedly be required for efficient harvest at scales required to sustain feedstock for conversion to biofuels.

Harvesting natural populations of seaweeds in nearshore environments has been controversial due to its environmental consequences. The destructive nature of harvesting methods in seaweed growing areas is of concern (Pringle et al., 1989). As a result, strict regulations have been put in place in some countries to manage seaweed harvests, stipulating percentages of harvestable stock allowed to be harvested and the intervals between harvests to allow growth and recovery of biomass (Ugarte et al., 2001). The establishment of large offshore seaweed farms may alleviate pressure on nearshore environments and 
could create market opportunities for products apart from fuels. However issues related to sustainability and potential environmental consequences will need to be carefully evaluated.

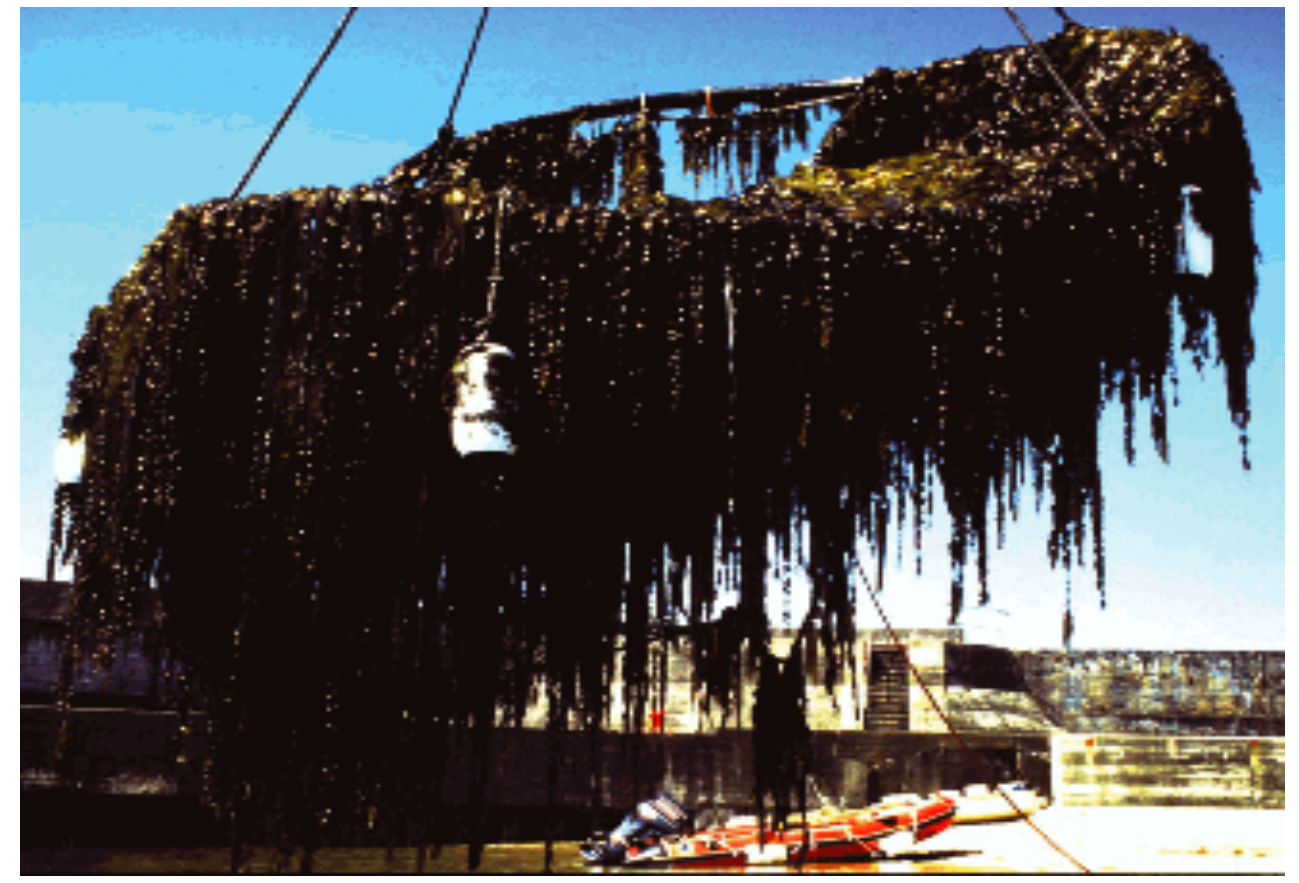

Figure 7. Harvest of Laminaria hyperborea grown on an offshore ring structure in the North Sea (Buck et al., 2004a).

\subsection{Preprocessing}

The general preprocessing requirements of macroalgal biomass prior to substrate extraction or direct conversion has been categorized as follows (Bruton et al., 2009):

- Removal of foreign objects and debris, e.g., by washing

- Milling

- Dewatering

Seaweeds, immediately following harvest, can have stones, sand, litter, adhering epifauna and other forms of debris that should be removed before further processing. Screening for debris is considered mandatory, with the degree of screening dependent on the mode of culture and end use. Algae that are grown in suspension culture, as opposed to attached to the bottom culture, will likely have less debris and have less impact during subsequent processing (Bruton et al., 2009).

Milling is used to reduce seaweeds to particle sizes that are more efficiently processed. Smaller particles, with higher surface area to volume ratios, will have higher reaction efficiency during anaerobic digestion for biogas, fermentation for alcohols, and hydrothermal liquefaction for bio-oils.

Unlike microalgae, in which production and extraction of lipids is a primary goal, macroalgae have less of a demand for dewatering as part of the pretreatment process. Anaerobic digestion, fermentation, and 
hydrothermal liquefaction have either a high tolerance or requirement for water. Dewatering may be more important as a method to increase shell life and reduce weight and associated transportation costs, if algae are to be transported from sites of harvest and initial collection to distant processing plants (Bruton et al., 2009). Dewatering to about 20 to $30 \%$ water content is noted to have a stabilizing influence, beneficial for transportation and other processes requiring further drying (Bruton et al., 2009). In anaerobic digestion and fermentation, shredded or milled macroalgal biomass can go directly into either reactions or extractions. In these cases, "dewatering" occurs during the chemical processing to remove water from digested slurries (Chynoweth, 2002) or preparation of polysaccharide extracts for fermentation (Horn et al., 2000a; Horn et al., 2000b), not as part of the preprocessing steps. Hydrothermal conversions are suited for wet biomass and becomes efficient at 15 to $20 \mathrm{wt} \%$ solids or 80 to $85 \%$ water content (Peterson et al., 2008). Although some dewatering of seaweeds whose water content approaches $90 \%$ may be necessary, the exact ratio of water to solids for marine biomass remains to be determined.

\subsection{Types of Biofuels and Conversion Technology for Macroalgae}

Macroalgae possess high levels of structural polysaccharides that are potential biochemical feedstocks for production of liquid biofuels (Table 8). However, a number of compounds are unique, and their distribution differs across the major macroalgal taxonomic groups (i.e., brown, green, and red seaweeds).

Table 8. Carbohydrate composition of macroalgae.

\begin{tabular}{ccc}
\hline Brown Algae & $\begin{array}{c}\text { Macroalgae Taxa } \\
\text { Green Algae }\end{array}$ & Red Algae \\
\hline Laminarin & Starch & Carrageenan \\
Mannitol & Cellulose & Agar \\
Alginate & & Cellulose \\
Fucoidin & & Lignin \\
Cellulose & \\
\hline
\end{tabular}

This creates a need to assess the implications for species selection and associated conversion technologies. Green algae possess carbohydrate signatures typical of higher plants; however, they are low in cellulose. Brown and red algae possess unique carbohydrates, precluding direct translation of technologies developed for conversion of biochemical feedstocks in higher plants. As a group, macroalgae have a low cellulose content and, until recently (Martone et al., 2009), believed not to possess lignins.

Compounds such as alginate, carrageenan, and agar have commercial value and represent potential coproducts for existing markets. These compounds are unique to macroalgae and some, such as alginates, which occur in high concentrations in brown seaweeds, are considered recalcitrant to fermentation since the redox balance favors formation of pyruvate as the end product (Forro, 1987). Polysaccharides and sugar alcohols in brown algae, e.g., laminarin and mannitol, are candidate feedstocks for conversion to liquid fuels. Lipids in a variety of macroalgae are typically less than $5 \%$ of total dry weight (Mcdermid et al., 2003), too low for conversion to biodiesel, although concentrations approaching $20 \%$ are reported in a few species (Chu et al., 2003; Mcdermid et al., 2003). Because of low lipid levels, production of biofuels 
from macroalgae is expected to depend on conversion of carbohydrate feedstocks, rather than extraction of energy-rich oils that can be processed to biodiesel or hydrocarbons.

The compositional differences between macroalgal and terrestrial biomasses are of interest, and in Table 9 , the compositions of different seaweeds species are listed and compared to selected terrestrial biomass feedstock, including wood chips, switchgrass, and corn stalk.

Table 9. Composition of different seaweed species and selected lignocellulosic feedstocks.

\begin{tabular}{|c|c|c|c|c|c|c|c|}
\hline Compositions, \% w/w & $\begin{array}{c}\text { Macrocystis } \\
\text { (Brown } \\
\text { seaweed) } \\
\end{array}$ & $\begin{array}{c}\text { Laminaria } \\
\text { (Brown } \\
\text { seaweed) } \\
\end{array}$ & $\begin{array}{c}\text { Gracilaria } \\
\text { (Red }^{3} \\
\text { seaweed) } \\
\end{array}$ & $\begin{array}{c}U l v a^{4, a} \\
\text { (Green } \\
\text { seaweed) }\end{array}$ & $\begin{array}{l}\text { Hybrid } \\
\text { poplar }^{5}\end{array}$ & $\begin{array}{c}\text { Summer } \\
\text { switch- } \\
\text { grass }^{5}\end{array}$ & $\begin{array}{c}\text { Corn } \\
\text { stover }^{5}\end{array}$ \\
\hline Water & 88.2 & 88 & & & 6.9 & 13.3 & 6.1 \\
\hline Total solids & 11.8 & 12 & & & 93.1 & 86.7 & 93.9 \\
\hline \multicolumn{8}{|l|}{$\begin{array}{l}\text { Proximate Analysis, } \\
\text { dry basis, } \% \mathrm{w} / \mathrm{w}\end{array}$} \\
\hline Ash & 41.1 & 26 & $37.7 \pm 3.6$ & 30.2 & 2.7 & 2.7 & 5.1 \\
\hline Volatile Solids (VS) & 58.9 & 74 & $\begin{array}{c}62.3 \pm 3.6 \\
\text { (calculated) }\end{array}$ & 69.8 & 84.8 & 82.9 & 80.9 \\
\hline Protein & 17.3 & 12 & $11.4 \pm 2.3$ & 13.6 & & & \\
\hline Lipids & -- & 2 & & 2.7 & & & \\
\hline Mannitol & 20.2 & 12 & & & & & \\
\hline Laminarin & 0.8 & 14 & & & & & \\
\hline Alginates & 15.3 & 23 & & & & & \\
\hline Cellulose & 5.2 & 6 & & & & & \\
\hline Fucoidin & 0.2 & 5 & & & & & \\
\hline \multicolumn{8}{|l|}{$\begin{array}{l}\text { Elemental analysis, dry } \\
\text { basis, } \% \mathrm{w} / \mathrm{w}\end{array}$} \\
\hline $\mathrm{C}$ & 28.0 & 34.6 & & 31.6 & 50.2 & 47.5 & 46.8 \\
\hline $\mathrm{H}$ & 3.92 & 4.7 & & & 6.06 & 5.8 & 5.74 \\
\hline $\mathrm{O}$ & $24.3^{\mathrm{b}}$ & 31.2 & & & 40.4 & 43.6 & 41.4 \\
\hline $\mathrm{N}$ & 1.86 & 2.4 & & 2.18 & 0.6 & 0.36 & 0.66 \\
\hline S & 1.09 & 1 & & 3.1 & 0.02 & 0.05 & 0.11 \\
\hline $\mathrm{P}$ & 0.33 & 0.35 & & 0.2 & & & \\
\hline K & 0.014 & 0.0096 & & & & & \\
\hline $\mathrm{HHV}, \mathrm{MJ} / \mathrm{kg}$, dry basis & $\mathrm{n} / \mathrm{a}$ & 13.2 & & & 19.0 & 18.6 & 18.4 \\
\hline $\mathrm{LHV}, \mathrm{MJ} / \mathrm{kg}$, dry basis & 11.0 & 12.1 & & & 17.7 & 17.3 & 16.8 \\
\hline
\end{tabular}

Note: ${ }^{a}$ Average values of Ulva at different months; ${ }^{\mathrm{b}}$ Analyzed based on empirical formula in Chynoweth and Srivastava (1980).

${ }^{1}$ Chynoweth et al (1980); ${ }^{2}$ Reith et al (2005); ${ }^{3}$ Msuya et al (2002); ${ }^{4}$ Briand et al (1997); ${ }^{5}$ Phyllis Database for Biomass and Waste: http://www.ecn.nl/phyllis.

Seaweeds generally have higher ash content and lower heating values than the terrestrial biomass (11 to $12 \mathrm{MJ} / \mathrm{kg}$ vs. 17 to $18 \mathrm{MJ} / \mathrm{kg}$ ). The seaweed metal content (especially alkali metals) is also higher than the 
terrestrial biomass. Total halogen content is in the range $0.5-11 \%$ in kelps which is also significantly higher than terrestrial biomass (1-1.5\%) (Ross et al., 2008). The high alkali content can be a concern for component integrity in dedicated systems for macroalgae conversion. Since mineral contents in seaweed vary with the growth cycle of seaweed, the cultivation of seaweed can be investigated and harvesting adjusted to control the mineral level (Ross et al., 2008). Seaweeds also have higher nitrogen, sulfur, and mineral contents. The much higher sulfur content of seaweeds requires a higher removal cost for biofuels production from macroalgae than terrestrial biomass feedstock. The high nitrogen content is also a potential concern, and its removal may be required.

Brown seaweed is the single largest macroalgae resource and is considered to be one of the most likely candidates for energy processing (Bruton et al., 2009). The primary carbohydrates in brown seaweeds are 1) mannitol, a sugar alcohol, 2) laminarin, a beta-1,3 linked glucan that also contains mannitol, 3) alginic acid, which is composed of mannuronic and guluronic acids, and 4) fucoidins, a sulfonated fucan that contains other sugars such as galactose, xylose, and uronic acid (Percival et al., 1967). An advantage for macroalgae compared to terrestrial biomass is the paucity of lignin type materials, which is resistant to conversion during biofuels production.

Apart from anaerobic digestion, which is considered to be economically feasible (Chynoweth et al., 2001), other conversion technologies, particularly those that lead to liquid transportation fuels are at an early stage or yet to be actively investigated. Microorganisms capable of fermenting the laminarin and mannitol of Laminaria hyperborea to ethanol have been identified and partially characterized (Horn et al., 2000a; Horn et al., 2000b). Thermochemical conversion can utilize both the carbohydrate and lipid fractions as substrates (Ross et al., 2008). Hydrothermal liquefaction, in particular, may be an appropriate conversion technology for biomass that has a high water content (Peterson et al., 2008). Catalytic hydroprocessing can further convert the bio-oils produced by hydrothermal liquefaction to hydrocarbon compounds that are more desirable for use in infrastructure-compatible liquid fuels (Elliott et al., 2009). Future priorities would include approaches that lead to conversion of macroalgae to other advanced fuels such as butanol and hydrocarbon-based chemicals, conversion of recalcitrant major substrates in seaweed, e.g., alginate, and direct thermal conversion to bio-oils and hydrocarbon-based products. Production of such liquid fuels from macroalgal feedstock, together with an approach to produce feedstock at a scale and cost needed to positively impact the biofuels economy, are current challenges.

Methane or biogas (methane plus $\mathrm{CO}_{2}$ ) is a demonstrated biofuel product from seaweed and can be produced via anaerobic digestion (Matsui et al., 2006; Bruton et al., 2009). Different species of seaweeds have been tested for biogas production, mainly Macrocystis, Laminaria, Gracilaria, Sargassum, and Ulva (Gunaseelan, 1997; Chynoweth et al., 2001). The biogas production from seaweed process has been demonstrated to be technically viable, however the cost of this process is still high and there is a need to reduce the cost of the raw material by at least $75 \%$ over current levels before it is competitive in the current market (Bruton et al., 2009). The methane yields and conversion efficiencies for different seaweeds are listed in Table 10. Seaweeds have methane yields ranging from 0.14 to $0.40 \mathrm{~m}^{3} / \mathrm{kg}$ volatile solids (VS). This is similar to methane production from primary sewage sludge and therefore a suitable raw material for anaerobic fermentation (Reith et al., 2005). 
Table 10. Methane yields and conversions efficiencies for different macroalgae (based on biochemical methane potential assays $)^{1}$.

\begin{tabular}{lcccc}
\hline Yields and efficiencies & Macrocystis & Laminaria & Gracilaria & Ulva \\
\hline$\%$ ash-free dry weight reduction & $34-80$ & $46-60$ & $50-85$ & 62 \\
Methane Yield, Mg-C/Mg VS & $0.08-0.21$ & $0.12-0.16$ & $0.15-0.21$ & 0.17 \\
Methane Yield, $\mathrm{m}^{3} / \mathrm{kg} \mathrm{VS}^{1,2}$ & $0.14-0.40$ & $0.23-0.30$ & $0.25-0.31$ & $0.22-0.33$ \\
\hline
\end{tabular}

Note: ${ }^{\mathrm{a}} \mathrm{VS}=$ ash-free dry wt. $\left(550^{\circ} \mathrm{C}\right) ;{ }^{\mathrm{b}}$ Calculated based on methane gas density of $0.656 \mathrm{~kg} / \mathrm{m} 3$ at $25^{\circ} \mathrm{C}$ (http://physics.info/density/); ${ }^{\mathrm{c}}$ Calculated based on VS mass fraction in dry seaweed listed in Table 9.

${ }^{1}$ Chynoweth et al (2001) citing Marine (1990); ${ }^{2}$ Gunaseelan (1997)

Ethanol is currently produced by fermentation of sugars from agricultural raw materials such as sugar cane and corn. The most readily accessible carbohydrates in brown seaweed are mannitol and laminaran (a storage glucan). In Laminaria, for example, mannitol and laminaran make up about 26\% (Table 9) of the total dry mass. The polysaccharides in seaweed will require a new commercial process to break them down into their constituent monomers prior to fermentation, or a direct fermentation process will need to be developed (Bruton et al., 2009). Experimental work has been initiated in Norway to generate ethanol by fermentation of brown seaweeds using the yeast Pichia angophorae (Horn et al., 2000a). Irish researchers in National University of Ireland Galway have isolated an enzyme from the thermophilic aerobic fungus Talaromyces emersonii to breakdown complex sugars into simple sugars, and a research group in China is investigating alginate lyases (Bruton et al., 2009). Fermentation of green seaweed to ethanol is being studied in Denmark at the National Environmental Research Institute, Aarhus University. The starch in green seaweed may be easier to ferment than carbohydrates in brown seaweed when using standard bacteria or yeast strains, and cultivation conditions under stress is being tested to increase production (Bruton et al., 2009). The challenges in the development of fermentation technology for seaweed include identifying suitable microorganisms and genes for hydrolysis. These challenges may be solved by using modern biochemical and genetic tools and rapid developments in the field of industrial enzymes and fermentation technology (Reith et al., 2005).

Other potential biofuels products from seaweed also include bio-oil and biodiesel. Aresta (2005b) conducted experimental work for the production biodiesel from Chaetomorpha linum, a green macroalgae. Hydrothermal liquefaction (HTL) and supercritical carbon dioxide extraction processes were studied. HTL involves the processing of wet biomass in a pressurized reactor, usually in the presence of a catalyst, to produce two liquid phases: aqueous and organic. The results are summarized in Table 11.

Table 11. Biodiesel from Green Macroalgae (Chaetomorpha linum).

\begin{tabular}{lll}
\hline Process & Thermochemical Liquefaction & Supercritical $\mathbf{C O}_{2}$ Extraction \\
\hline Conditions & 350 to $395{ }^{\circ} \mathrm{C}$ & $50^{\circ} \mathrm{C}$ and $2.60 \mathrm{MPa}$ \\
& & $(7 \mathrm{hours}$, methanol co-solvent $)$ \\
Yield & $80 \mathrm{mg} / \mathrm{g}$ dry matter & $45 \mathrm{mg} / \mathrm{g}$ dry matter \\
\hline
\end{tabular}

The unsaturated and saturated fatty acids produced from this algae have a carbon range between 14 and 24 , in addition to hydrocarbons and phytols. HTL is more effective than the supercritical carbon dioxide extraction, but the higher temperature required for HTL may cause some oil to decompose. The yields for both methods at $4.5-8 \mathrm{~kg}$ per $100 \mathrm{~kg}$ of dry algae are low and suggest an area for further research. In 
contrast the HTL yield for wood chips is about $35 \mathrm{wt} \%$ of dry feedstock. However, the fatty acid carbon range from seaweed of 14 and 24 is closer to the conventional diesel carbon range than the heavier wood based bio-oil (Feng et al., 2004). HTL of brown seaweed is estimated to produce bio-oil yields of 23

$\mathrm{kg} / 100 \mathrm{~kg}$ dry seaweed for light crude and $10 \mathrm{~kg} / 100 \mathrm{~kg}$ dry seaweed for heavy crude (Reith et al., 2005). This estimation is closer to bio-oil production from wood.

Depending upon the conversion methods, either wet or dry macroalgae can be used. Anaerobic fermentation or liquefaction can directly use wet feedstock (Chynoweth et al., 2001; Aresta et al., 2005b). Extraction of bio-oil from seaweed requires dry feedstock, which can be achieved using solar energy or process heat (Aresta et al., 2005a). 


\subsection{Preliminary Economic Assessment}

\subsection{Seaweed Production Costs as Reported in Literature}

Seaweed production in Asia is mostly cultivated, while, in Europe, it is currently from harvesting natural seaweeds populations. There is a significant difference in production cost between the cultivated seaweed and natural grown seaweed because of the difference in productivity. Important examples of cultivation systems include rope farms, tidal flat farm, and floating cultivation system. Table 12 shows the productivity and production costs for large-scale cultivated seaweeds.

Table 12. Seaweed yields and production costs from marine biomass.

\begin{tabular}{lcccc}
\hline System & \multicolumn{2}{c}{ Yield } & Production Cost \\
\cline { 2 - 3 } & Daf $^{\mathbf{1}} \mathbf{M T} / \mathbf{h a} / \mathbf{y r}$ & Dry MT/ha/yr & \$/dw MT \\
\hline Macrocystis, nearshore & 50 & 83 & 25 \\
Laminaria/Laminaria rope farm & 45 & 59 & 112 \\
(offshore) & & & \\
Ulva/Ulva, tidal flat farm & 23 & 30 & 21 \\
Sargassum, floating cultivation & 45 & 47 & 25 \\
\hline
\end{tabular}

Source: Reith et al (2009), citing Chynoweth (2002)

Daf $=$ dry and ash free

The estimated production cost, including capital and operating costs, ranges from $\$ 21$ to $\$ 112$ per dry metric ton. The capital cost includes the containment system and the harvesting system. The annual operating and maintenance cost consists of farm maintenance and seaweed cultivation. A simplified seaweed production process is shown in Figure 8.

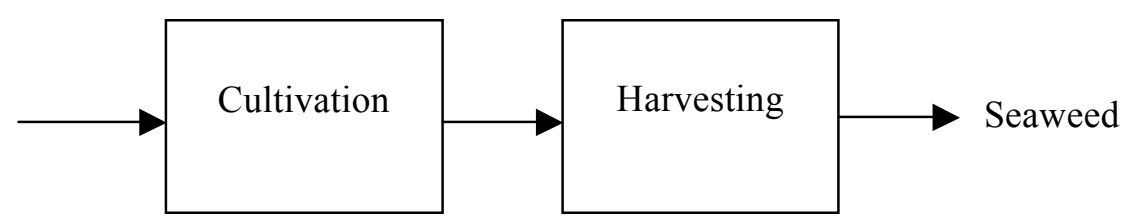

Figure 8. Block flow for seaweed production process.

As shown in Table 12, the production cost decreases as the seaweed yield per unit area increases. These values are in general approximation of those estimated by Oilgae (2010), who reported production costs of $\$ 75$ and $\$ 150$ per dry metric ton as a function of the scale of production (Oilgae, 2010). The high cost of the Gracilaria/Laminaria rope farm is likely due to the farther offshore location as compared to nearshore location of the other farms. However, Chynoweth (2002) points out that productivity comparisons should not be used to suggest that one approach is more cost effective than another. There are many factors associated with the different seaweed production systems, i.e. different nutrients, scale, 
geographical climate, and country of production (many Asian countries versus those in Europe). Thus, the differences are too big to allow comparison at a common condition.

\subsection{Fuel Production Cost Estimation}

Three seaweed conversion processes are considered: 1) methane production followed by conversion to gasoline through syngas and methanol, 2) fermentation to ethanol and 3) hydrothermal liquefaction to gasoline and diesel. Cost assumptions are largely based on a study by Reith et al (2005) and Jones and Zhu (Jones et al., 2009a; Jones et al., 2009b).

\subsubsection{Gasoline from Seaweed via Digestion and MTG Production Description}

The simplified process flowsheet for Methanol-to-Gasoline (MTG) production is shown in Figure 9. In this process, seaweed is first digested to generate biogas, approximately composed of $35 \mathrm{vol} \% \mathrm{CO}_{2}$ and $65 \mathrm{vol} \% \mathrm{CH}_{4}$ (Chynoweth et al., 2001). Laminaria japonica produces approximately $0.6 \mathrm{vol} \% \mathrm{H}_{2} \mathrm{~S}$ in the biogas product (Yokoyama et al., 2007), which must be removed prior to downstream conversion. After sulfur removal, the cleaned biogas is then sent to a steam reformer to convert methane to $\mathrm{CO}$ and $\mathrm{H}_{2}$ and adjust the $\mathrm{H}_{2}$ :CO ratio to about 2, as required for methanol synthesis. The reformed gas is then sent to an amine unit to remove $\mathrm{CO}_{2}$, compressed, and converted to methanol. The final step converts methanol to gasoline via the MTG process.

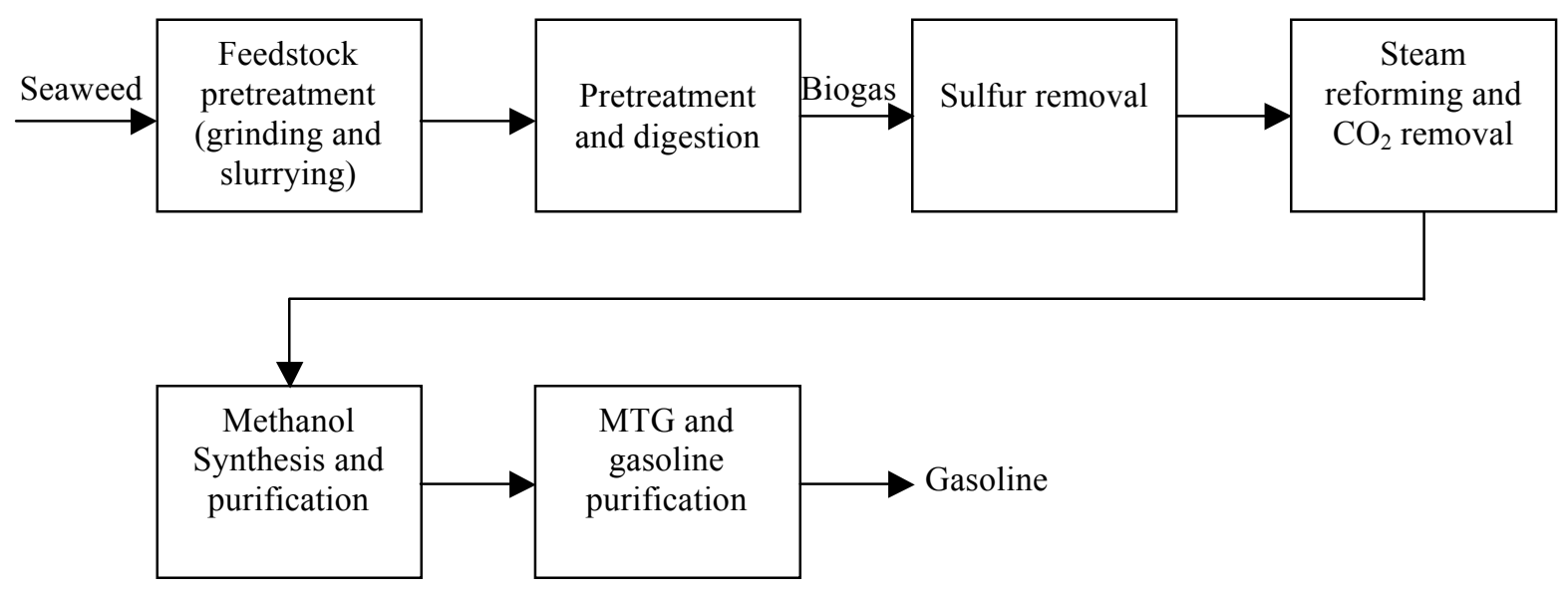

Figure 9. Block flow for seaweed to gasoline via digestion and MTG.

The steam reformer, methanol synthesis loop, and MTG technology are commercially available. The anaerobic digestion process is still in the demonstration phase. The major process assumptions for anaerobic digestion of brown seaweeds, Macrocystis sp. and Laminaria sp., from demonstration seaweed to biogas plants are listed in Table 13. The typical pretreatment process for seaweed is grinding or cutting to reduce the size of feedstock, followed by addition of water to form a slurry. The hydraulic retention time (HRT) for Macrocystis sp. digestion is shorter than Laminaria. The possible reason is that the laminarin and alginate content in Laminaria sp. is higher and thus requires more time for digestion. The 
biogas products for the two different brown seaweed species have similar composition, generally containing 60 to $65 \%$ methane.

Table 13. Process assumptions for macroalgae methane digestion.

\begin{tabular}{|c|c|c|}
\hline Seaweed & Macrocystis $^{1}$ & Laminaria $^{2}$ \\
\hline Kelp pretreatment & $\begin{array}{c}\text { Grind to size required, add } \\
\text { water for slurry }\end{array}$ & $\begin{array}{c}\text { Cut to several sq. mm, add water } \\
\text { until } 1 \text { to } 5 \% \text { total solids }\end{array}$ \\
\hline \multicolumn{3}{|l|}{ Anaerobic Digestion Conditions } \\
\hline Temperature, ${ }^{\circ} \mathrm{C}$ & 22 & $\begin{array}{l}\text { Pre-digestion: } 25-35 \\
\text { Digestion: } 55\end{array}$ \\
\hline $\mathrm{pH}$ & $\mathrm{n} / \mathrm{a}$ & $>7.5$ \\
\hline Load rate, $\mathrm{kg} \mathrm{VS} / \mathrm{m}^{3}$ digester-day ${ }^{\mathrm{a}}$ & 1.6 or $3.2^{3}$ & 1.1 to $1.65^{3}$ \\
\hline Retention time, day & $7-18^{3}$ & 15 to 25 \\
\hline \multicolumn{3}{|l|}{ Bio gas products } \\
\hline Methane, vol\% & 60 & $60-65$ \\
\hline $\mathrm{CO}_{2}, \mathrm{vol} \%$ & 40 & $35-40$ \\
\hline
\end{tabular}

The digestion design by Reith et al. (2005) was used as the basis for methane production in this report. Seaweed biomass with a $12 \%$ dry matter concentration immediately after harvesting is slurried and pumped to the digestor reactor. Digestion takes place at $35^{\circ} \mathrm{C}$, and the HRT was assumed to be 20 days. Reith et al also considered a 30 day retention time. The heat for the digesters is provided by combusting part of the biogas. The solids containing liquid effluent is post-treated to recover $\mathrm{N}$ and $\mathrm{P}$, which can be recycled as seaweed fertilizer or sold as a by-product.

\subsubsection{Ethanol from Seaweed Fermentation Production Description}

In the ethanol production process shown in Figure 10, the seaweed is pretreated and then sent to a fermentation reactor. The complex composition of seaweeds makes it a difficult substrate to produce ethanol by using one or a few strains of microbes in fermentation. Based on the proposed bioethanol fermentation concept proposed by Reith et al. (2005), the seaweed feedstock is first ground to small pieces and sent to an undefined pretreatment process that is followed by enzymatic hydrolysis. After hydrolysis, the solution can be evaporated to increase the concentration if necessary. Then the solution is send to the fermenters to produce ethanol. The assumption used by Reith that $50 \%$ of the dry seaweed is fermentable to ethanol is very ambitious and still needs research (Reith et al., 2005). The raw ethanol is distilled and dehydrated to a moisture content of $99.9 \mathrm{vol} \%$ as required by fuel quality specifications. The fermentation residues are combusted to generate electricity and heat. Pretreatment, enzymatic hydrolysis, and fermentation conversion are all largely notional with respect to seaweed, thus the assumed yields are speculative and on the order of that for expected for cellulosic ethanol from corn stover. 


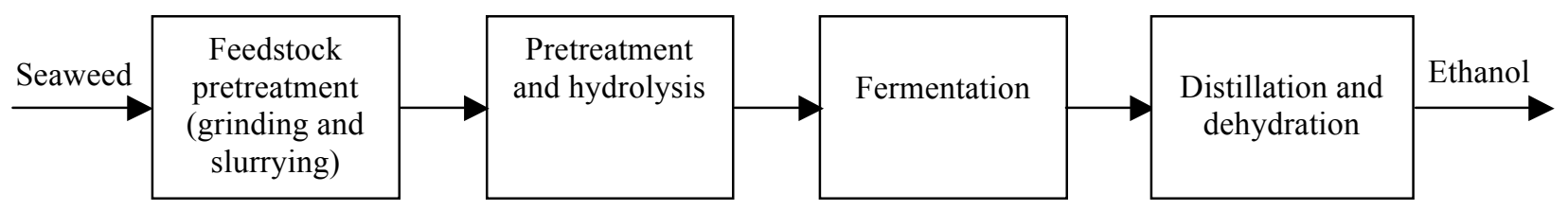

Figure 10. Block flow for seaweed to bioethanol via fermentation.

\subsubsection{Gasoline and Diesel via HTL and Bio-Oil Upgrading Production Description}

The simplified flow scheme for HTL coupled with catalytic upgrading of the resultant bio-oils to gasoline and diesel is shown in Figure 11. HTL is a suitable treatment method for wet feeds such as seaweeds that have a high polysaccharide level and low or no lignin. In this process, seaweed is ground, slurried with recycled water $(>10 \%$ on the dry feedstock) and then pumped to the HTL reactor. The HTL reaction takes place at $120-180$ bar and $300-350{ }^{\circ} \mathrm{C}$ for 5-15 minutes. High pressure is needed to keep the water in the liquid phase. The HTL reactor generates an oil phase, an aqueous phase, and a gas product. The aqueous phase consists of water and dissolved organics. The oil phase is a wide boiling range bio-crude with an oxygen content that is less than that of the starting biomass. The gas phase is a low BTU gas mainly composed of carbon dioxide.

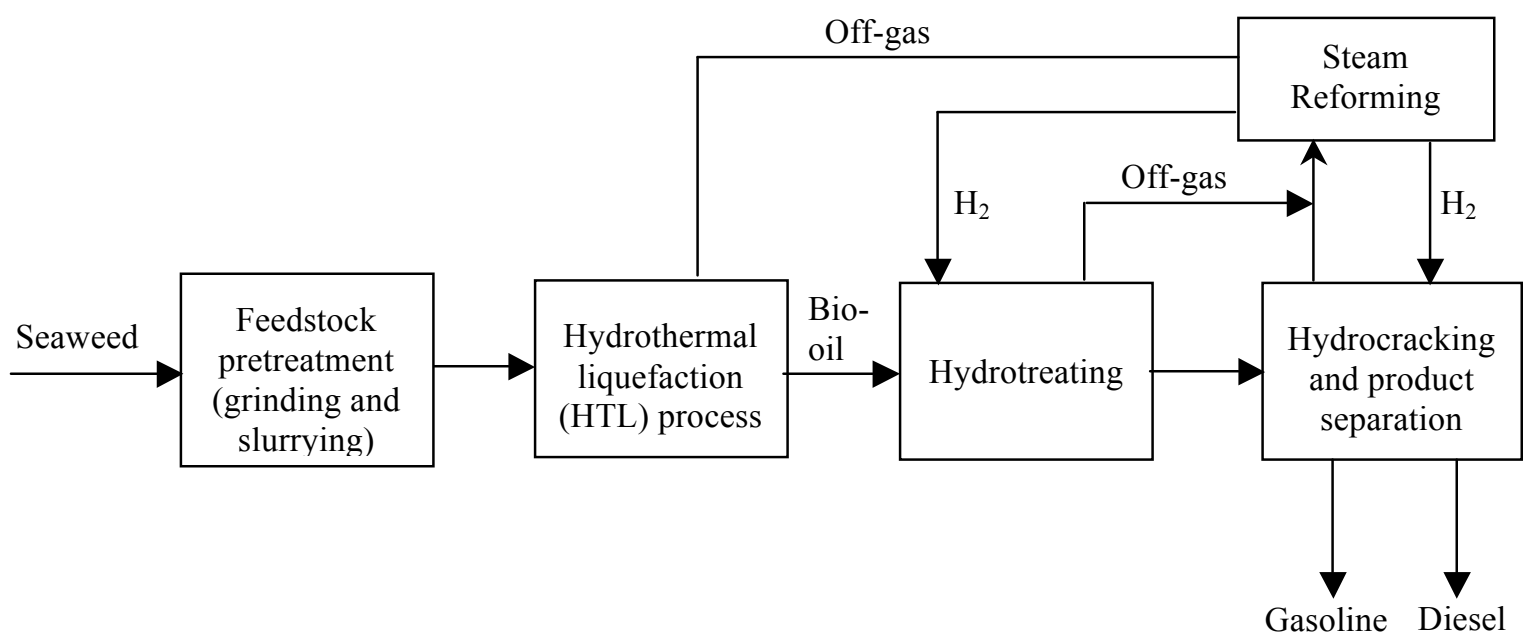

Figure 11. Block flow for seaweed to gasoline and diesel via HTL and upgrading.

While some literature information is available for the HTL portion of the process on wet feeds such as sugar beet pulp (Goudriaan et al., 2001), no public data are available concerning upgrading the HTL oil to fuel. The upgrading step is assumed to be similar to that described in (Jones et al., 2009a). The bio-oil is sent to an upgrading unit to completely deoxygenate the bio-oil and crack the heavier products into gasoline and diesel through hydrotreating and hydrocracking. The hydrogen used for upgrading is assumed to the generated from steam reforming of the upgrading offgas and supplemental natural gas. Because of the lack of composition data for bio-oil from seaweed, the hydrogen consumption for bio-oil upgrading of wood HTL is used as a basis for this process (Jones et al., 2009a). A major assumption for 
this process is that the sulfur and nitrogen content of the bio-oil does not affect the quality of the final products.

\subsubsection{Cost Analysis Basis}

The cost analysis is partly based on that developed for evaluation of the technical and economic feasibility of seaweed cultivation in the North Sea in combination with offshore wind parks target for 2020 and conversion of seaweed biomass to biofuels (Reith et al. 2005). The Reith study evaluated the cost for conversion of the brown seaweed Laminaria to methane, ethanol, and bio-oil at an onshore processing location with scales of 100,000 dry metric tons and 500,000 dry metric tons. Their results indicate that the seaweed conversion at the 100,000 metric tons/year scale is too small for commercial production, thus a scale of 500,000 metric tons/year is assumed. The capital and operating costs for conversion of seaweed to methane and ethanol via fermentation and the bio-oil via HTL as used by Reith et al. (2005) are listed in Table 14. Note that the cost to produce the seaweed is not included.

Table 14. Estimated production and cost for biofuels conversion from seaweed ${ }^{1}$ (Reith et al., 2005).

\begin{tabular}{|c|c|c|c|}
\hline Products & Methane & Ethanol & HTL Biocrude \\
\hline Scale (metric ton/yr, dry basis) & 500,000 & 500,000 & 500,000 \\
\hline Conversion rate, dry seaweed & $0.124 \mathrm{~m}^{3} / \mathrm{kg}$ & $0.254 \mathrm{~kg} / \mathrm{kg}$ & $\begin{array}{l}0.2278 \mathrm{~kg} / \mathrm{kg} \text { light crude; } \\
0.0976 \mathrm{~kg} / \mathrm{kg} \text { heavy crude }\end{array}$ \\
\hline Byproducts & $\mathrm{n} / \mathrm{a}$ & $\begin{array}{c}\text { Electricity } \\
212,778 \mathrm{MWh} / \mathrm{yr}\end{array}$ & $\mathrm{n} / \mathrm{a}$ \\
\hline Project Investment, million USD ${ }^{2}$ & 41.5 & 243 & 151.1 \\
\hline $\begin{array}{l}\text { Operating cost, excluding } \\
\text { seaweed cost, million USD/yr }{ }^{2}\end{array}$ & 4.2 & 29.3 & 19.1 \\
\hline Net production (per yr) & 61.8 million $\mathrm{m}^{3}$ & 127,000 metric ton & $\begin{array}{c}113,900 \text { metric ton } \\
\text { light crude } \\
48,800 \text { metric ton } \\
\text { heavy crude }\end{array}$ \\
\hline
\end{tabular}

Note: ${ }^{1}$ Based on brown seaweed, Laminaria sp.; ${ }^{2}$ Converted from 1 Euro $=1.3$ USD

Comparing the methane conversion rate used by Reith et al. (2005) ( Table 14) with the ranges shown in Table 10 suggests that the Reith case is very conservative. Therefore, the methane case as presented by Reith may have room for improvement.

In contrast, for ethanol production, the assumption of 50\% ethanol yield from seaweed has not yet been demonstrated, and likely will need additional research to achieve. In addition, a reduced enzyme cost compared to the commercial price is assumed in the Reith model (Reith et al., 2005). Therefore, this example of ethanol production from seaweed represents a future design case and has much better performance compared to the current technical development status of this process. 
To estimate the total cost of production to finished fuels, downstream production costs are added to the results from the Reith study. For the seaweed to gasoline via fermentation and MTG processes, the production cost of methane conversion to methanol and MTG are calculated based on the economic model developed for wood (Jones et al., 2009b). The production cost of the bio-oil upgrading and purification is based on the study by Jones et al (2009a).

\subsubsection{Performance and Cost Analysis Results}

The techno-economic analysis results for conversion of seaweed systems to three biofuels are shown in Table 15. It should be noted that none of these processes are completely proven experimentally, and that the HTL upgrading process is at best notional. The maximum allowable feedstock prices for seaweed are estimates for each system. The production costs of either intermediate or final products are estimated without considering the feedstock cost. These costs are deducted from the average market prices to obtain a maximum feedstock price. All costs are reported in 2008 dollars.

As shown in Table 15, the gasoline from methane yield is much lower than the other two cases because of the assumed low methane yield from seaweed and the carbon loss to $\mathrm{CO}_{2}$ during fermentation. The combined production costs of $\$ 2.58$ /gallon combined with the low methane yield results in the need for a negative feedstock cost. This suggests that the process is not viable at the assumed methane yield of the Reith study of $0.124 \mathrm{~m}^{3} / \mathrm{kg}$ dry seaweed $\left(0.17 \mathrm{~m}^{3} / \mathrm{kg}\right.$ VS seaweed assuming $74 \%$ VS in dry seaweed). This is at the lower end of the methane yield range listed in Table 10. Figure 12 shows the effect of the yield range shown in Table 10. At methane yields of about $0.16 \mathrm{~m}^{3} / \mathrm{kg}$ dry seaweed, the seaweed maximum allowable price becomes positive. At $0.22 \mathrm{~m}^{3} / \mathrm{kg}$ dry seaweed, the seaweed maximum allowable price rises to approximately $10 \$ /$ dry metric ton.

Table 15. Fuel product cost results (2008 annual average dollars).

\begin{tabular}{|c|c|c|c|}
\hline Products & Gasoline & Ethanol & Gasoline/diesel \\
\hline Main technology & $\begin{array}{c}\text { Fermentation and } \\
\text { MTG }\end{array}$ & Fermentation & $\begin{array}{l}\text { HTL and } \\
\text { Upgrading }\end{array}$ \\
\hline Feedstock, dry metric ton/day & 500,000 & 500,000 & 500,000 \\
\hline Intermediate products & Methane & $\mathrm{n} / \mathrm{a}$ & HTL bio-oil \\
\hline Final products & Gasoline & Ethanol & Gasoline and Diesel \\
\hline Final product yield, million gal/yr & 11 & 42 & 39 \\
\hline \multicolumn{4}{|l|}{ Production costs ${ }^{1}$} \\
\hline Seaweed to intermediate product, $\$ /$ gallon & 1.40 & 1.80 & 1.50 \\
\hline $\begin{array}{l}\text { final product } \\
\text { Intermediate to final product, \$/gallon final } \\
\text { product }\end{array}$ & 1.50 & $\mathrm{n} / \mathrm{a}$ & 1.20 \\
\hline $\begin{array}{l}\text { Final product } 2008 \text { market average price, } \\
\text { \$/gallon }\end{array}$ & 2.60 & 2.20 & $2.80^{2}$ \\
\hline $\begin{array}{l}\text { Maximum allowable feedstock price, } \$ / \text { dry } \\
\text { metric ton }\end{array}$ & -6 & 28 & 6 \\
\hline
\end{tabular}

Note: ${ }^{1}$ Excludes feedstock cost, all costs rounded nearest $\$ 0.10 ;{ }^{2}$ Rounded average of gasoline price and diesel price in 2008

The ethanol yield in Table 15 is higher than the other processes on a per gallon bases probably due to the high conversion rate used for seaweed to ethanol and the fact that it is an oxygenated product. The ethanol 
case also has the highest maximum allowable seaweed price, which is within the range of the current seaweed production cost listed in Table 12. But this case is based on optimal design assumptions of future type target. Based on the current technical development status, the maximum feedstock price for the bioethanol fermentation is likely to be much higher than the value obtained in this study.

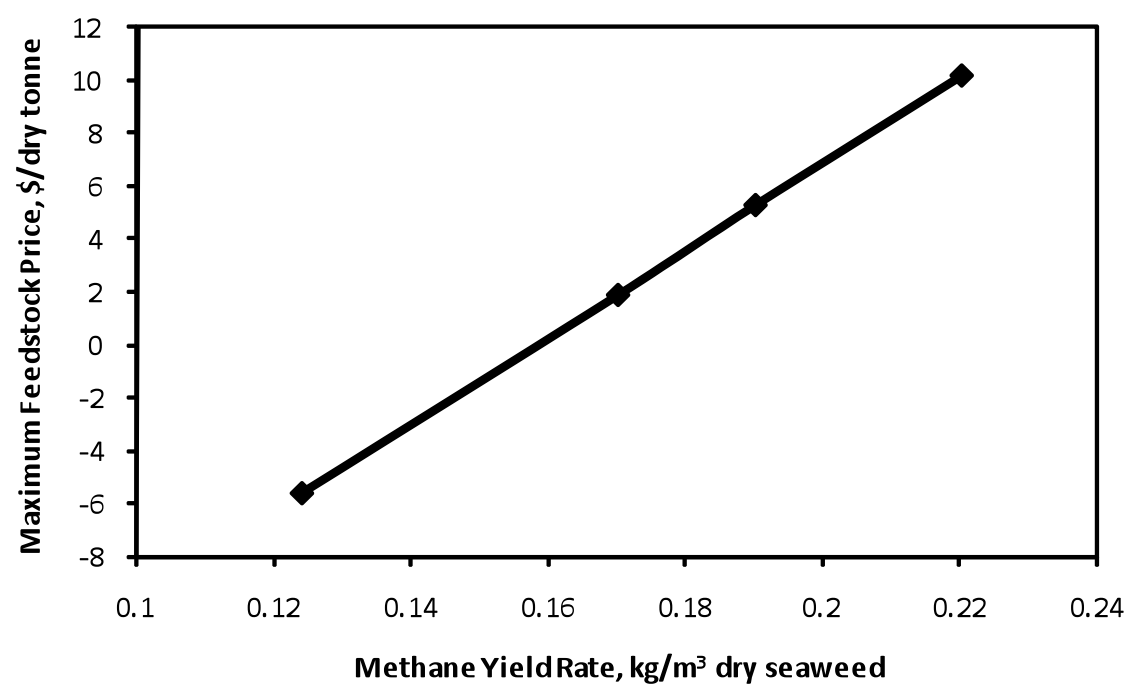

Figure 12. Affect of methane yield on minimum feedstock price for the MTG process.

The seaweed to gasoline/diesel via HTL case also has a positive maximum allowable feedstock price, but is lower than the current seaweed production price even for large scale cultivation farms. Additionally, the upgrading steps are not demonstrated and thus this case represents the most risk from a technology standpoint.

\subsubsection{Co-Production of High Value Products}

Potential organic co-products from seaweeds such as alginates, mannitol, L-fraction, fucoidan, plant protein, and phenolic compounds have the potential to improve the economics of fuel production. The inorganic co-products mainly include potash and iodine (Tompkins, 1983). With 15\% of seaweed used for co-production of alginates, mannitol, and iodine, the biofuel production cost was estimated to decrease 50 to $80 \%$ for a seaweed-to-methane conversion plant (Tompkins, 1983). Assuming in the methane-togasoline plant that $15 \%$ of the seaweed is used for the co-products, the production cost of the seaweed to methane step can be reduced by $60 \%$. Therefore, the maximum allowable feedstock price can be about $\$ 12 /$ dry metric ton even with a low conversion to methane.

Three conversion processes for seaweed to liquid biofuels were evaluated. The estimation of seaweed to gasoline via fermentation and MTG are based on the current existing technology, while ethanol via fermentation and gasoline/diesel via HTL and upgrading are based on a future potential technology. The maximum feedstock price was then back-calculated from the fuel production costs and ranged from negative to nearly $\$ 30 /$ dry metric ton. This is at the low end of estimated seaweed production costs, suggesting that improvements in processing throughout the supply chain are needed to make fuel production viable. 


\subsection{Energy and Emissions Related Studies}

For any alternative fuel in development, it is important to determine the range of environmental impacts associated with production of that fuel. Life cycle analysis (LCA) is a comprehensive method that may be used to estimate the impacts of a fuel, ideally from the feedstock production phase through the fuel combustion process (i.e., "well-to-wheel"). A literature review of LCA and energy analysis studies for macroalgae-based fuels was conducted in order to provide a baseline of information for future studies.

\subsection{Product Life Cycle}

The life cycle of fuels derived from macroalgae (seaweed) is illustrated in Figure 13. Feedstock may be derived from wild or cultivated seaweed or collected on the beach (drift). The taxa Macrocystis pyrifera, Laminaria, Gracilaria, Sargassum, Ulva, and others that have high productivities have all been considered as potential biomass sources for energy production (Oilgae, 2010). Note that harvest of wild seaweed beds may have significant impacts on marine habitat/ecosystems and comprehensive studies on these effects are necessary to determine the full effects of using this feedstock as a source of fuel.

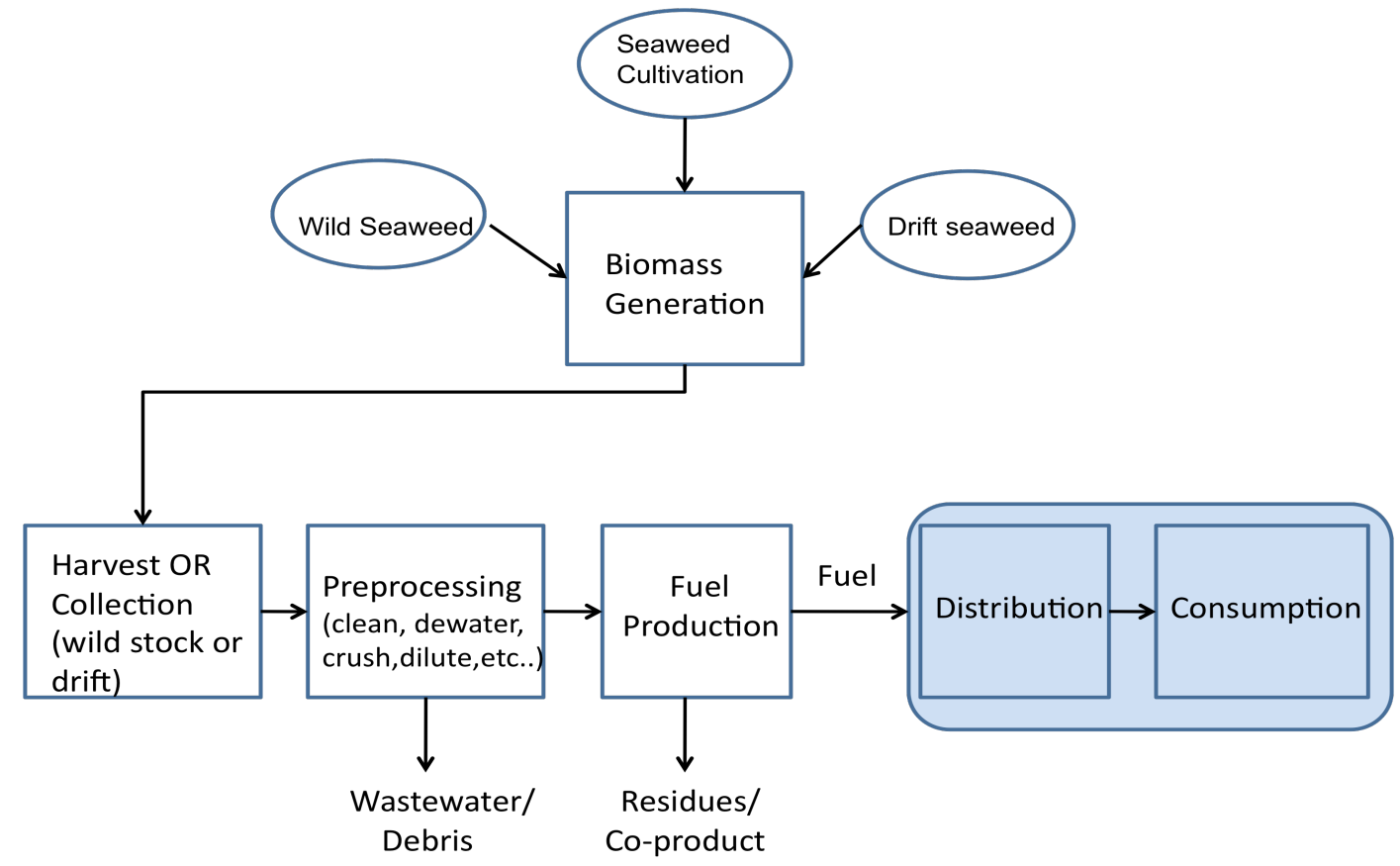

Figure 13. Primary steps in the macroalgal fuel life cycle.

After harvest or collection, seaweed is usually preprocessed to some extent to remove any debris, extra water, and other impurities undesirable for downstream processing. Dewatering is carried out primarily for increasing shelf life and decreasing costs associated with transporting to the fuel plant and any drying that may be necessary. Generally, dewatering is performed to produce a biomass product of $20-30 \%$ water 
content (Bruton et al., 2009). Since drying is energy intensive, it should be avoided whenever possible (unless via solar means). One advantage of using seaweed for fuels is that higher moisture feeds can be easily used in the likely fuel production processes (Hennenberg et al., 2009). The preprocessing stage may also include removal of salt, polyphenols, and sulphated polysaccharides to increase yields from fermentation processes (Bruton et al., 2009).

After the necessary preprocessing, the feedstock is transported to the fuel production plant if separately located. Fuel production options for macroalgae included in this review are anaerobic digestion to methane, fermentation to alcohols, and bio-oil production, with anaerobic digestion being the most developed pathway currently (Hennenberg et al., 2009). The distribution and consumption phase should be the same regardless of feedstock and is not included here.

LCAs of macroalgae-based fuels are sparse in the published literature. There are a few studies, however, that give a general idea of the energy requirements for the main processes involved in the life cycle. Most of these are focused on feedstock generation through the fuel production phase (excluding fuel distribution and consumption phases, see Figure 13). The studies identified are summarized in the following paragraphs.

\subsection{Anaerobic Digestion to Biogas}

Anaerobic digestion is a biological process that is used to produce methane-rich gas from biomass. The digestion process generally consists of the following steps: 1) hydrolysis of organic matter, 2) synthesis of acetic acid from hydrolysis products, and 3) methane gas generation by methanogenic bacteria. The overall conversion of cellulose to methane can be represented by the following reaction:

$$
\mathrm{C}_{6} \mathrm{H}_{10} \mathrm{O}_{5}+\mathrm{H}_{2} \mathrm{O} \rightarrow 3 \mathrm{CO}_{2}+3 \mathrm{CH}_{4}
$$

Seaweed is of similar composition as other organic material sources and should be adaptable to existing anaerobic digestion process plants. However, the presence of compounds associated with seaweed, such as salts, can inhibit the fermentation process, so preprocessing involving washing is necessary to prevent inhibition.

Anaerobic digestion of macroalgae produces a biogas consisting of about $60 \%$ methane and $40 \% \mathrm{CO}_{2}$ (and variable trace amounts of $\mathrm{CO}, \mathrm{N}_{2}, \mathrm{H}_{2}, \mathrm{H}_{2} \mathrm{~S}$, and $\mathrm{O}_{2}$ ). Heating values for macroalgae biogas range from 29.33 to $29.83 \mathrm{MJ} / \mathrm{m}^{3}$ biogas (1 $\mathrm{kg}$ dry wt. gives $0.5 \mathrm{~m}^{3} \mathrm{CH}_{4}$ gas at STP) (Beavis et al., 1987). The conversion efficiencies for anaerobic digestion of macroalgae and microalgae lie in approximately the same range (Beavis and Charlier 1987).

The biochemical methane potential for kelp (Macrocystis pyrifera) is reported as $0.39-0.41 \mathrm{~L} / \mathrm{g}$ volatile solids (VS) (Chynoweth et al., 2001). Volatile solids (wet weight minus ash content) are useful to describe the chemically convertible content in the biomass (Beavis et al., 1987). Marine plants generally have higher ash content and thus lower VS content and heating values than terrestrial biomass (Ross et al., 2008). Also, seaweed composition can vary with season and geographic location, and depends on the part of the plant used, which can all affect the product yield as well (Kelly, 2006). For example, it was found that the methane yield from the brown algae Saccharina latissima was doubled for material harvested during autumn as compared to spring (Ostgaard et al., 1993).

The software package COMPUBIO was developed for evaluating the energy balance of various biofuels pathways, including micro and macro algae (Aresta et al., 2005a). Energy consumption values for the different stages of the lifecycle are estimated, but emissions (e.g., GHGs) are not included in the study. 
The analysis results in a net energy on the order of $11,000 \mathrm{MJ} /$ metric ton dry algae for macroalgae, compared to $9,500 \mathrm{MJ} /$ metric ton for micro-algae. To provide an idea of how each step of the process contributes to the overall energy usage, consumption results for individual stages are summarized from the study as follows:

- Flue gas $/ \mathrm{CO}_{2}$ capture and transport to cultivation lagoon: $\sim 1.75 \mathrm{MJ} / \mathrm{kg} \mathrm{CO} 2$

- Algae production and harvesting: $\sim 12.2 \mathrm{MJ}$ consumed/kg algae

- Cultivation $=2.15 \mathrm{MJ} / \mathrm{kg}$ algae (applies to both micro- and macro-)

- Nutrient supply $=4.55 \mathrm{MJ} / \mathrm{kg}$ algae (applies to both micro- and macro-)

- Harvesting $=5.5 \mathrm{MJ} / \mathrm{kg}$ algae (lagoon)

- Drying $=0.0 \mathrm{MJ} / \mathrm{kg}$ algae (drying through solar energy)

- Fuel production $=2.66 \mathrm{MJ}$ consumed $/ \mathrm{kg}$ biomass

The authors state that these are preliminary results and further study is needed for economic and environmental assessments of the processes. However, no follow-up LCA research to this study in the literature was found to date.

\subsection{Fermentation to Alcohols}

Fermentation of biomass to ethanol consists of two reactions: 1) hydrolysis of organic material to simple sugars (using high temperature, acids or enzymes), and 2) fermentation of sugars to ethanol via the following reaction:

$$
\mathrm{C}_{6} \mathrm{H}_{12} \mathrm{O}_{6} \rightarrow 2 \mathrm{CH}_{3} \mathrm{CH}_{3} \mathrm{OH}+2 \mathrm{CO}_{2}
$$

Adaptation of current fermentation technology for cellulosic biomass resources to accept seaweed as a feedstock should not be difficult (Adams et al., 2009). However, ethanol yields are generally not as high as with more established fermentation processes (Hennenberg et al., 2009).

An analysis of the life cycle stages of seaweed cultivation, harvest, and ethanol production (Aizawa et al., 2007) was conducted for macroalgae (kelp and wakame) that would be farmed and harvested in coastal or offshore zones with techniques already used in Japan. The macroalgae biomass would be processed into ethanol using highly efficient fermentation technologies. Ethanol yield was assumed to be $27 \mathrm{~kg} / \mathrm{metric}$ ton raw seaweed ( $=34 \mathrm{~L} /$ metric ton raw seaweed or $0.27 \mathrm{~kg} / \mathrm{kg}$ dry seaweed). This is low compared to corn ( $\sim 463 \mathrm{~L} /$ metric ton) because of the high water content of seaweed biomass. Resource consumption for cultivation through production was estimated, however little background or references for data sources is given. The study estimates that the overall energy balance for seaweed ethanol is comparable to corn ethanol, with about a $70 \%$ reduction from conventional gasoline.

An energy and emissions analysis has been conducted for a hypothetical process for an integrated multitrophic aquaculture farm (St. Peter et al., 2010). The system boundaries of the study included the cultivation of juvenile seaweed at a fish hatchery (growing off of fish waste products), grow-out and harvest of adult seaweed, seaweed slurry production (milling), and fermentation and purification of mixed organic acids. Transportation of juvenile plants to the grow-out facility and the adult seaweed to the conversion facility was also included.

Numerical results were not included in the study, which was presented in abstract form. However some general conclusions were given on the relative contribution of individual stages of the process. Of the multiple impacts associated with the process, uptake and emissions of $\mathrm{CO}_{2}$, phosphorous and nitrogen 
were identified of prime importance. The juvenile grow-out phase, the marine grow-out phase and the distillation process were determined to be the most significant energy intensive phases of the process. The juvenile grow-out phase requires large quantities of water (i.e. pumping energy) and the marine grow-out phase requires much maintenance (i.e., fuel for transportation vessels). Distillation, which requires large amounts of steam, was identified as the greatest consumer of energy. Electricity was the primary form of energy consumed for the processes studied. Strategies to improve energy efficiency, such as scale-up of the grow-out system, energy efficient pumps, utilizing gravity more in aquaculture, increased process integration, and increased crop density are discussed briefly. Recycling of $\mathrm{CO}_{2}$ from fermentation processes back to the algae growing process, in the case of integrated facilities, may also be possible (Hennenberg et al., 2009).

Studies that provide yield data for the cultivation, purification/separation, and fermentation processes (Horn et al., 2000b; Morchio et al., 2009; Goh et al., 2010), useful parameters for an LCA, were also reviewed . A third-generation bioethanol biorefinery based on macroalgae feedstock was conceptualized with an assumed ethanol yield of $\sim 0.08 \mathrm{~kg} / \mathrm{kg}$ dry seaweed (Goh et al., 2010). Morchio et al (2009) estimated an ethanol yield of $15 \mathrm{~L} / 100 \mathrm{~kg}$ dry macroalgae ( $=0.12 \mathrm{~kg}$ ethanol $/ \mathrm{kg}$ dry macroalgae). A related study (Horn et al. 2000b) reported a yield of $0.38 \mathrm{~kg}$ ethanol $/ \mathrm{kg}$ mannitol, which equates to 0.10 $\mathrm{kg}$ ethanol $/ \mathrm{kg}$ dry seaweed, assuming a seaweed mannitol content of $25 \%$. The results of these three studies are in close approximation of each other.

\subsection{Bio-oil Extraction}

While microalgae have been the focus for biodiesel production due to their generally higher lipid content, there has been some work on bio-oil production from macroalgae, through either extraction or liquefaction technology (Aresta et al., 2005b; Bastianoni et al., 2008; Zhou et al., 2010).

A comparative analysis of the energy balance and environmental efficiency of producing bio-oil was conducted for feedstock from macroalgae and sunflower (Bastianoni et al., 2008). The system boundaries included were the cultivation, harvest, and oil extraction processes. For the seaweed case, cultivation/harvest energy was considered zero because the seaweed is currently being collected and landfilled as waste to alleviate eutrophication of a lagoon. Macroalgae bio-oil was extracted with chloroform and methanol, while sunflower oil was mechanically extracted. The study uses "emergy analysis", which is a methodology where all types of input are converted to a common energy unit, in this case, the solar emjoule (sej), using a conversion factor, or transformity (Odum, 1988). A comprehensive inventory for the growth/harvesting and oil extraction phases, including fossil energy usage, as well as materials usage (steel) for boats and the extraction plant, labor, and natural energy flows (rain, wind, N, P, etc.) were considered.

The analysis resulted in an emergy investment of $8.93 \times 10^{6} \mathrm{sej} / \mathrm{J}$ macroalgae oil, versus $2.78 \times 10^{5} \mathrm{sej} / \mathrm{J}$ sunflower oil, showing that the extraction process for macroalgae uses about 30 times more natural resources than sunflower oil. This was due primarily to much higher inputs of chemicals and electricity for the extraction process in the macroalgae case. The macroalgae oil was also seen as not profitable based on the actual oil yield.

As previously mentioned, these results did not consider the energy and materials consumed during the collection of the feedstock because it is currently collected as waste. The input data for the seaweed collection phase was included in the study and may be useful in future LCA studies. Specific input data of interest are shown in Table 16. 
Table 16. Resource consumption data for macroalgae fuel (Bastianoni et al., 2008).

\begin{tabular}{lc}
\hline \multicolumn{1}{c}{ Processing Step } & Resource Consumption (per g oil) \\
\hline Growth and Harvesting & \\
Diesel Fuel & $9.6 \mathrm{~J}$ \\
\hline Lubricants & $1933 \mathrm{~J}$ \\
Electricity (water exchange between & $100 \mathrm{k} \mathrm{J}$ \\
sea and lagoon) & \\
Oil Extraction & \\
Electricity & $645 \mathrm{~kJ}$ \\
Water & $240 \mathrm{~g}$ \\
Chemicals (solvent extraction) & $152 \mathrm{~g}$ methanol \\
& $283 \mathrm{~g}$ chloroform \\
\hline
\end{tabular}

\subsection{Seaweed Cultivation and Harvesting Stages}

Macroalgae cultivation farms will require energy inputs to sustain the cultivation and harvesting phases. In a study conducted for the Marine Biomass Program, energy usage for cultivation and harvesting for a 100,000 acre open-ocean kelp farm was reported to have fuel requirements for pumping deepwater nutrients to the ocean surface in the range of 3.0-6.0 MMBtu/ wet metric ton seaweed for a yield of 10 metric ton/acre/year (mid-range analyzed) (Ashare et al., 1978). This method of providing nutrients has been identified to be prohibitively expensive in some situations because of the high energy requirements (Chynoweth, 2002). Harvesting requirements were in the range of 0.6-2.1 MMBtu/ wet metric ton. Location of kelp farms in natural upwelling areas with the use of passive, wave-driven pumps remains an option.

\subsection{State of LCAs for Macroalgae}

Comprehensive LCAs of macroalgae-based fuels are scarce in the published literature. This review provides a summary of the primary life cycle stages and current published knowledge on the energy and mass balance of macroalgae fuel systems. A thorough assessment of sustainability issues, including energy, air, water, land, soil, and biodiversity, is necessary to provide an adequate comparison with other fuels, and facilitate improved process design of macroalgal fuel production systems. 


\subsection{Summary Findings}

The photosynthetic efficiency of aquatic biomass with an average 6 to $8 \%$ is much higher than the average photosynthetic efficiency of 1.8 to $2.2 \%$ for terrestrial biomass (Aresta et al., 2005a). Thus, the intrinsic productivity of aquatic biomass is high. The resource potential of macroalgae as an energy feedstock is considered to exceed that of all terrestrial biomass by about three-fold (Chynoweth et al., 2001). Nevertheless, the feasibility of macroalgae cultivation at the scale required for a biofuels market and its associated costs are uncertain. Key questions relating to utilizing this biomass center on 1) where and how it can be produced and 2) the economic feasibility of this production and its conversion to liquid fuels.

The United States was the first country to attempt cultivation of marine biomass as a biofuels feedstock with a program to grow kelp in offshore open ocean farms for methane production during the 1970s and 1980s. The results led to conclusions that conversion of marine biomass to methane was feasible, but the technology to grow the biomass had yet to mature and remained problematic (Chynoweth et al., 2001). This effort was taking place during a period of oil shortages and high oil prices. The recovery of oil prices resulted in the curtailment of this program, and interest in cultivation of macroalgae as a biofuels feedstock has only recently been renewed because of the current priority on the development of renewable fuels to replace petroleum. The goal to replace petroleum derived fuels with renewable fuels as put forth in the 2007 EISA has led the United States to set a target of 36 billion gallons of renewable fuels by 2022. Marine biomass in the form of macroalgae can potentially help meet these goals. However, serious challenges need to be addressed in order to bring the concept of marine biomass as a renewable fuels feedstock to fruition.

While it was believed that production of fuels from marine biomass would be competitive with production from other biomass sources (Chynoweth et al., 2001), the current industry focus is on developing infrastructure-compatible, liquid transportation fuels, rather than methane as a bio-gas in the earlier work. Thus, reconsideration of the feasibility of both biomass production and its conversion to fuels is appropriate at this time. As we pointed out in the current study, improvements in processing throughout the supply chain are needed, and maximum allowable feedstock costs are at the bottom of the current range of feedstock production costs.

Although the marine biomass resource potential for the United States is very high based on the surface area of the U.S. EEZ and known rates of macroalgae production in other parts of the world, the United States does not currently have a macroalgae production industry. The feasibility of producing the large amount of marine biomass needed as a biofuels feedstock in U.S. waters remains to be examined in detail Large scale, sustainable production of macroalgae biomass for biofuels is constrained by a number of critical physical factors including, but not limited to following conditions:

- climate,

- water depth,

- available sunlight,

- water circulation patterns and velocities,

- turbidity,

- seasonal ocean temperature variation,

- seasonal nutrient availability, 
- $\quad$ suitability of sites for farms.

There is also a need to consider socio-political factors critical to cultivation operations in the coastal zone and offshore waters that can potentially limit siting macroalgal cultivation and processing facilities in regions where environmental conditions may otherwise be suitable. These include factors such as the following:

- activities related to industry,

- population centers,

- military sites,

- $\quad$ shipping lanes,

- recreation,

- marine sanctuaries

- development of other marine energy systems (e.g., wind and tidal power)

Thus, in order to determine the feasibility of macroalgal cultivation as a renewable fuels biomass feedstock, a resource assessment is needed to accurately identify cultivation sites that meet the requirements of both suitable environmental conditions for growth at the scales needed and competing use constraints. Such information, together with the costs of production in selected locations, is needed for a definitive evaluation of the sustainability of macroalgae production.

In summary, initial findings suggest that the marine biomass resource potential for the United States is very high based on the surface area of the U.S. coastal waters and known rates of macroalgae production in other parts of the world. However, macroalgae cultivation for fuels production is likely a long term effort. The United States does not currently have a macroalgae production industry. Replacing $1 \%$ of the domestic gasoline supply would require annual production that is about ten and one-half times current worldwide production. Advances in cultivation technology can be expected to increase the efficiency of future production of macroalgae. Understanding how to harness this untapped biomass resource requires additional research and development into macroalgae cultivation, harvesting and conversion to fuel. 


\subsection{References}

Adams, J. M., J. A. Gallagher and I. S. Donnison (2009). Fermentation study on Saccharina latissima for bioethanol production considering variable pre-treatments. Journal of Applied Phycology 21(5): 569-574.

Aizawa, M., K. Asaoka, M. Atsumi and T. Sakou (2007). Seaweed bioethanol production in Japan - The Ocean Sunrise Project. Oceans 2007, Vancouver, Canada.

Aresta, M., A. Dibenedetto and G. Barberio (2005a). Utilization of macro-algae for enhanced CO2 fixation and biofuels production: Development of a computing software for an LCA study. Fuel Processing Technology 86(14-15): 1679-1693.

Aresta, M., A. Dibenedetto, M. Carone, T. Colonna and C. Fragale (2005b). Production of biodiesel from macroalgae by supercritical $\mathrm{CO} 2$ extraction and thermochemical liquefaction. Environmental Chemistry Letters 3(3): 136-139.

Ashare, E., D. C. Augenstein, A. C. Sharon, R. L. Wentworth, E. H. Wilson, D. L. Wise and R. D. C. Dynatech (1978). Cost analysis of aquatic biomass systems - final report. Cambridge, MA, Dynatech R/D Company.

Bastianoni, S., F. Coppola, E. Tiezzi, A. Colacevich, F. Borghini and S. Focardi (2008). Biofuel potential production from the Orbetello lagoon macroalgae: A comparison with sunflower feedstock. Biomass \& Bioenergy 32(7): 619-628.

Beavis, A. and R. H. Charlier (1987). An economic appraisal for the onshore cultivation of Laminaria spp. Hydrobiologia 151/152: 387-398.

Bird, K. T. and J. Benson (1987). Seaweed Cultivation for Renewable Resources. Amsterdam, Elsevier Science Ltd.

Brekke, K. (2007). Butanol: An energy alternative. EthanolToday March 2007: 36-39.

Briand, X. and P. Morand (1997). Anaerobic Digestion of Ulva Sp. 1. Relationship Between Ulva Composition and Methanisation. Journal of Applied Phycology 9(6): 511-524.

Bruton, T., H. Lyons, Y. Lerat, M. Stanley and M. B. Rasmussen (2009). A review of the potential of marine algae as a source of biofuel in Ireland. Dublin, Ireland, Sustainable Energy Ireland.

Buck, B. H. and C. M. Buchholz (2004a). The offshore-ring: A new system design for the open ocean aquaculture of macroalgae. Journal of Applied Phycology 16(5): 355-368.

Buck, B. H., G. Krause and H. Rosenthal (2004b). Extensive Open Ocean Aquaculture Development within Wind Farms in Germany: The prospect of Offshore Co-management and Legal Constraints. Ocean Coastal Management 47(3-4): 95-122.

Buck, B. H. and V. Smetacek. (2006). Aquafarm Roter Sand. 2007, from awi.de/de/forschung/neue technologien aquaculture.

Buck, H. B. a. C. M. B. (2005). Response of Offshore Cultivated Laminaria saccharina to Hydrodynamic Forcing in the North Sea. Aquaculture 250: 674-691.

Choi, J. S., J. Y. Cho, L. G. Jin, H. J. Jin and Y. K. Hong (2002). Procedures for the axenic isolation of conchocelis and monospores from the red seaweed Porphyra yezoensis. Journal of Applied Phycology 14(2): 115-121.

Chu, W.-L., M. Norazmi and S. M. Phang (2003). Fatty acid composition of some Malaysian seaweeds. Malaysian Journal ofscience 22: 21-27.

Chynoweth, D. P. (2002). Review of Biomethane from Marine Biomass, University of Florida: 1-207.

Chynoweth, D. P., K. F. Fannin and V. J. Srivastava (1987). Biological gasification of marine algae. Seaweed Cultivation for Renewable Resources. K. B. a. P. Benson. Amsterdam, Elsevier: 285303.

Chynoweth, D. P., J. M. Owens and R. Legrand (2001). Renewable methane from anaerobic digestion of biomass. Renewable Energy 22(1-3): 1-8.

Chynoweth, D. P. and V. J. Srivastava (1980). Methane production from marine biomass. International symposium on biogas, microalgae, and livestock wastes. Taipei, Taiwan: 27. 
Collado-Vides, L. (2001). Clonal architecture in marine macroalgae: ecological and evolutionary perspectives. Evolutionary Ecology 15(4-6): 531-545.

EERE, B. P. (2010). Biomass Program Multi-Year Program Plan, March 2010.

EIA. (2008, January 26, 2010). Petroleum Statistics. Retrieved September 3, 2010, 2010.

Elliott, D. C., T. R. Hart, G. G. Neuenschwander, L. J. Rotness and A. H. Zacher (2009). Catalytic Hydroprocessing of Biomass Fast Pyrolysis Bio-oil to Produce Hydrocarbon Products. Environmental Progress \& Sustainable Energy 28(3): 441-449.

FAO (2008a). 2006 Fishery and Aquaculture Statistics.

FAO (2008b). Laminaria japonica. Cultured Species Information Programme: Aquaculture Fact Sheets: Cultured Aquatic Species, FAO Fisheries and Aquaculture Department. 2008.

Feng, F., J. van der Kooi and J. de Swaan Arons (2004). Biomass conversions in subcritical and supercritical water: driving force, phase equilibria, and thermodynamic analysis. Chem. Eng. Process. 43: 1459-1467.

Forro, J. (1987). Microbial degradation of the marine biomass. Seaweed Cultivation for Renewable Resources. K. T. B. a. P. H. Benson. Amsterdam, Elsevier: 305-325.

Friedlander, M. (2008). Israeli R \& D activities in seaweed cultivation. Israel Journal of Plant Sciences 56(1-2): 15-28.

GAO (2005). Understanding the factors that influence the retail price of gasoline, U. S Government Accountability Office.

Goh, C. S. and K. T. Lee (2010). A visionary and conceptual macroalgae-based third-generation bioethanol (TGB) biorefinery in Sabah, Malaysia as an underlay for renewable and sustainable development. Renewable and Sustainable Energy Reviews 14: 842-848.

Goldburg, R. J., M. S. Elliott and R. L. Naylor (2001). Marine Aquaculture in the United States: Environmental Impacts and Policy Options. Arlington, VA, U.S.A.

Goudriaan, F., B. van de Beld, F. R. Boerefijn, G. M. Bos, N. J.E., S. van der Wal and J. A. Zeevalkink (2001). Thermal Efficiency of the HTU Process for Biomass Liquefaction. Thermochemical Biomass Conversion. A. V. Bridgwater. Oxford, Blackwell Science, LTD: 1312-1325.

Gunaseelan, V. N. (1997). Anaerobic digestion of biomass for methane production: A review. Biomass \& Bioenergy 13(1-2): 83-114.

Hanisak, M. D. (1987). Cultivation of Gracilaria and other marcoalgage in Florida for energy consumption. Seaweed Cultivation for Renewable Resources. K. T. B. a. P. H. Benson. Amsterdam, Elsevier: 191-218.

Hennenberg, K. J., U. Fritsche, R. Herrera, A. Eggert, M. Renato, S. Hunt and B. Bunnag (2009). Aquatic Biomass: Sustainable Bioenergy from Algae? Issue Paper, November 2009.

Horn, S. J., I. M. Aasen and K. Ostgaard (2000a). Ethanol production from seaweed extract. Journal of Industrial Microbiology \& Biotechnology 25(5): 249-254.

Horn, S. J., I. M. Aasen and K. Ostgaard (2000b). Production of ethanol from mannitol by Zymobacter palmae. Journal of Industrial Microbiology \& Biotechnology 24(1): 51-57.

IEA-Bioenergy (2010). Algae - The Future for Bioenergy, International Energy Agency. ExCo64 Workshop: 16.

Jones, S. B., J. E. Holladay, C. Valkenburg, D. J. Stevens, C. Walton, C. Kinchin, D. C. Elliott and S. Czernik (2009a). Production of Gasoline and Diesel from Biomass via Fast Pyrolysis, Hydrotreating and Hydrocracking: A Design Case. Richland, WA, Pacific Northwest National Laboratory.

Jones, S. B. and Y. Zhu (2009b). Techno-economic Analysis for the Conversion of Lignocellulosic Biomass to Gasoline via Methanol-to-Gasoline (MTG) Process. Richland, WA, Pacific Northwest National Laboratory.

Kelly, M. (2006). Wind, Wave, and Weed. British Bioenergy News 5: 16-17.

Kraan, S. (2010). Mass production of macroalgae, opportunities for value added ingredients from protein to phosphate. Algal Biomass Summit. Phoenix, AZ. 
Marine-Biomass-Workshop (1990). A Summary Description of the Second workshop on the Role of Macroalgal Ocean Farming in Global Change. Newport Beach, CA, Electric Power Research Institute.

Martone, P. T., J. M. Estevez, F. C. Lu, K. Ruel, M. W. Denny, C. Somerville and J. Ralph (2009). Discovery of Lignin in Seaweed Reveals Convergent Evolution of Cell-Wall Architecture. Current Biology 19(2): 169-175.

Matsui, T., T. Amano, Y. Koike, A. Saiganji and H. Saito (2006). Methane fermentation of seaweed biomass. American Institute of Chemical Engineers Annual Meeting, San Francisco, CA, Omnipress.

Mcdermid, K. J. and B. Stuercke (2003). Nutritional Composition of Edible Hawaiian Seaweeds. Journal of Applied Phycology 15(6): 513-524.

McHugh, D. J. (2003). A Guide to the Seaweed Industry, Food and Agricultural Organization: 106.

Morchio, R. and C. Cáceres (2009). Macroalgae Current State in Latin America. International Workshop on Sustainable Bioenergy from Algae. Berlin, Germany.

Msuya, F. E. and A. Neori (2002). Ulva reticulata and Gracilaria crassa: Macroalgae That Can Biofilter Effluent from Tidal Fishponds in Tanzania. Western Indian Ocean J. Mar. Sci. 1: 117-126.

Neushul, M. (1989). Seaweed for War: California's World War I Kelp Industry. Technology and Cultures 30(3): 561-583.

Odum, H. T. (1988). Self-organization, transformity, and information. Science 242(4882): 1132-1139.

Oilgae (2010). Oilgae guide to fuels from macroalgae. Tamilnadu, India.

Ostgaard, K., M. Indergaard, S. Markussen, S. H. Knutsen and A. Jensen (1993). Carbohydrate degradation and methane production during fermentation of Laminaria saccharina (Laminariales, Phaeophyceae). Journal of Applied Phycology 5: 333-342.

Percival, E. and R. H. McDowell (1967). Chemistry and Biochemistry of Marine Algal Polysaccharides. London and New York, Academic Press.

Peterson, A. A., F. Vogel, R. P. Lachance, M. Froling, M. J. Antal and J. W. Tester (2008). Thermochemical biofuel production in hydrothermal media: A review of sub- and supercritical water technologies. Energy \& Environmental Science 1(1): 32-65.

Pringle, J. D. and C. K. Tseng (1989). Overview of a workshop on production and utilization of commercial seaweeds - Qingdao, China, 1987. Journal of Applied Phycology 1: 83-89.

Reith, J. H., E. P. Deurwaarder, K. Hemmes, A. P. W. M. Curvers, P. Kamermans, W. Brandenburg and G. Zeeman (2005). Grootschalige teelt can zeewieren in combinatie met offshore windparken in de Nordzee, Energy Commission of the Netherlands.

Reith, J. H., W. Huijgen, J. van Hal and J. Lenstra (2009). Seaweed potential in the Netherlands. Macroalgae - Bioenergy Research Forum. Plymouth, UK.

Roesijadi, G., A. E. Copping, M. H. Huesemann, J. Forster and J. R. Benemann (2008). TechnoEconomic Feasibility Analysis of Offshore Seaweed Farming for Bioenergy and Biobased Products, Battelle Pacific Northwest Division Report Number PNWD-3931.

Ross, A. B., J. M. Jones, M. L. Kubacki and T. Bridgeman (2008). Classification of macroalgae as fuel and its thermochemical behaviour. Bioresource Technology 99(14): 6494-6504.

Santelices, B. (1999). A conceptual framework for marine agronomy. Hydrobiologia 399: 15-23.

St. Peter, A. L. and M. Pietrak (2010). Life Cycle Assessment of Macro Algae as a Bio-Fuel Feedstock Source. 2010 AIChE Spring Meeting, San Antonio, TX.

Tompkins, A. (1983). Marine Biomass Program 1982 Annual Report. Marine Biomass Program. Chicago, IL, Gas Research Institute.

Tseng, C. K. (1987). Some remarks on the kelp cultivation industry of China. Seaweed Cultivation for Renewable Resources. K. T. Bird and P. H. Benson. New York, Elsevier: 147-153.

U.S.DOE (2010). National Algal Biofuels Technology Roadmap.

Ugarte, R. and G. Sharp (2001). A new approach to seaweed management in Eastern Canada:the case of Ascophyllum nodosum. Cahiers de Biologie Marine 42: 63-70. 
Vandendriessche, S., M. Vincx and S. Degraer (2006). Floating seaweed in the neustonic environment: A case study from Belgian coastal waters. J Sea Research 55: 103-112.

Whitney, L. L. (1987). Macroalgal commercialization in the United States. Hydrobiologia 151/152: 183188.

Yokoyama, S., K. Jonouchi and K. Imou (2007). Energy Production from Marine Biomass: Fuel Cell Power Generation Driven by Methane Produced from Seaweed. World Academy of Science, Engineering and Technology 28: 320-323.

Zemke-White, W. L. and M. Ohno (1999). World seaweed utilisation: An end-of-century summary. Journal of Applied Phycology 11(4): 369-376.

Zhou, D., L. A. Zhang, S. C. Zhang, H. B. Fu and J. M. Chen (2010). Hydrothermal Liquefaction of Macroalgae Enteromorpha prolifera to Bio-oil. Energy \& Fuels 24: 4054-4061. 


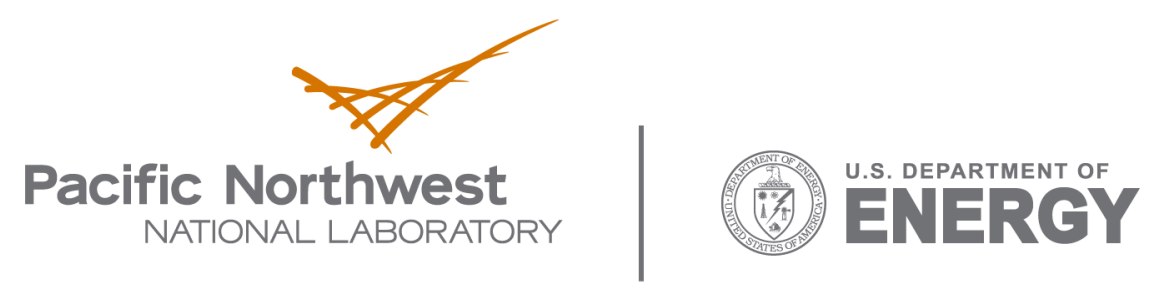

902 Battelle Boulevard

P.O. Box 999

Richland, WA 99352

1-888-375-PNNL (7665)

www.pnl.gov 